University of Zurich

Department of Economics

Working Paper Series

ISSN 1664-7041 (print)

ISSN 1664-705X (online)

Working Paper No. 20

\title{
Does Raising the Retirement Age Increase Employment of Older Workers?
}

Stefan Staubli and Josef Zweimüller

Revised version, May 2012 


\title{
Does Raising the Retirement Age
}

\section{Increase Employment of Older Workers?*}

\author{
Stefan Staubli, University of Zurich, University of St.Gallen and RAND, \\ Josef Zweimüller, University of Zurich, CEPR, CESifo and IZA
}

May 9, 2012

\begin{abstract}
Two pension reforms in Austria increased the early retirement age from 60 to 62 for men and from 55 to 58.25 for women. The reforms reduced early retirement by 18.9 percentage points among affected men aged $60-62$ and by 22.3 percentage points among affected women aged 55-58.25. The associated increase in employment was merely 6.8 percentage points among men and 10.1 percentage points among women. The reforms had large spillover effects to the unemployment insurance program but negligible effects on disability insurance claims. Specifically, unemployment increased by roughly 10 percentage points both among men and women. Spillover effects had substantial fiscal implications. Absent spillover effects, the reduction of net government expenditures would have amounted to 264 million Euros per year. Due to higher unemployment insurance claims and associated foregone income tax revenues the actual reduction was only 148 million Euros. High-wage and healthy workers carried the bulk of the fall in net government expenditures. Low-wage and less healthy workers generated much less government savings as they either continue to retire early via disability pensions or bridge the gap to regular retirement by drawing unemployment benefits.
\end{abstract}

Keywords: Retirement age, policy reform, labor supply, disability, unemployment JEL Classification Numbers: J14, J26

\footnotetext{
*Address: Stefan Staubli, IEW University of Zurich, CH-8000 Zurich, Switzerland; email stefan.staubli@econ.uzh.ch, tel +414463455 79. Josef Zweimüller, IEW University of Zurich, CH-8000 Zurich, Switzerland; email josef.zweimueller@econ.uzh.ch, tel +41 446343724.

We thank Philippe Ruh for excellent research assistance. We also thank Monika Bütler, Lukas Inderbitzin, Giovanni Mellace, Lucija Muehlenbachs, Uwe Sunde, and seminar participants at IZA, University of Salzburg, University of St. Gallen, University of Zurich, the 2012 Ski and Labor Seminar, the 2011 European Economic Association Meeting, and the 2011 Meeting of the Austrian Economic Society for helpful comments. Financial support by the Austrian National Science Research Network "Labor and Welfare State" of the Austrian FWF and the National Institute on Aging (R21AG037891) is gratefully acknowledged. All remaining errors are our own.
} 


\section{Introduction}

Aging populations put enormous pressure on public pension systems. ${ }^{1}$ These financial pressures are further enhanced by low and decreasing labor force participation rates of older individuals. As a consequence, many countries are considering (or have already implemented) pension reforms that cut retirement benefits and/or increase the statutory retirement age. ${ }^{2}$

Policy reforms that increase the statutory retirement age are difficult to implement for two main reasons. A first objection holds that, increasing the statutory retirement age is not an effective policy instrument, because the employment opportunities of older workers are weak. Increasing the retirement age is therefore unlikely to increase employment of older workers. Instead, it will increase unemployment benefit and disability benefit payrolls. Second, increasing the statutory retirement age is unfair because it mainly restricts the opportunity set of workers with the weakest labor market position while leaving unaffected workers whose labor market conditions are more favorable. Put differently, the less healthy workers in low-paid jobs (who have the highest incentive to retire) are hurt while the retirement age is much less binding for workers in good health in well-paid jobs.

In this paper we shed new light on these controversial issues by studying the impact of the Austrian pensions reforms of the years 2000 and 2003 that increased the early retirement age. The Austrian pension reforms implemented a gradual increase of the early retirement age (ERA): Between the years 2000 and 2010, the ERA was increased from age 60 to 62 for males and from age 55 to 58.25 for females. ${ }^{3}$

Our study has three main objectives. First, we study to which extent the increase in the ERA turned out to be an effective tool to increase employment of older workers. A series of previous studies that investigate the relationship between social security provisions and retirement have documented a sharp increase in retirement rates at the age of first

\footnotetext{
${ }^{1}$ Between 1970 and 2010 the average life expectancy at age 65 in OECD countries increased by roughly 4 years for men and 5 years for women. Over the same period the average retirement age has declined by almost one year. Forecasts suggest that there will be a further increase in life expectancy of around 3 years between 2010 and 2050 (OECD, 2011). The OECD projects that these forces will increase pension expenditures from 9.2 percent of GDP in 2007 to 12.7 percent of GDP in 2060 (OECD, 2011).

${ }^{2}$ For a summary of the reforms implemented in the 1990s see Schwarz and Demirguc-Kunt (1999). More recent reforms in industrialized countries are discussed in Gruber and Wise, eds (2007).

${ }^{3}$ Like in many other countries, Austrian retirement rules feature two statutory retirement ages: an ERA and a normal retirement age (NRA). While individuals can claim retirement benefits at a reduced rate upon reaching the ERA, they will only qualify for full retirement benefits at the NRA. The Austrian pension reforms left the NRA unchanged at age 65 for males and age 60 for females.
} 
eligibility for retirement benefits (Gruber and Wise, eds, 2007). Given this empirical regularity, an increase in the ERA is likely to be effective in delaying retirement and increasing employment of older workers.

A second main objective of our analysis is to investigate the importance of spillover effects of the ERA-increase into other social insurance programs (in particular, unemployment and disability insurance). For instance, previous studies have found that unemployment and/or disability insurance payrolls are often used as a gateway to early retirement. In many countries, enrollment in these programs has increased substantially in recent years and they have become an important channel by which workers drop permanently out of the work force. ${ }^{4}$ Understanding how a rise in the ERA affects inflow into other programs is also important to assess the consequences for government expenditures.

A third main objective of our analysis is therefore to explore the fiscal consequences (i.e. net reduction of government expenditures) of the increase in the ERA as well as its distributive implications (i.e. which types of workers contribute how much to the expenditure reduction). More precisely, we estimate the fiscal implications by translating the labor market effects into corresponding changes in overall retirement benefit payments, social security contributions and earnings taxes as well as changes in overall unemployment and disability benefit payments. Since the ERA-increase affected high- and low-wage workers differently, it is important to account for these heterogenous effects to correctly estimate the fiscal consequences. At the same time, accounting for effect-heterogeneity also allows us to study in detail the distributive consequences of the ERA-increase and to explore the extent to which the burden of the ERA-increase is indeed carried by low-wage workers in bad health.

We think that understanding the consequences of the pension reforms in Austria is of general interest for at least three reasons. First, the institutional features of the Austrian old-age social security, while differing in the details, share many features in other countries. In many public pension systems there is both an ERA and a NRA. Many countries allow older workers to permanently retire through unemployment insurance and disability insurance, often providing preferential treatment for older workers. Hence, we think that evaluating the Austrian pension reform will contribute to a better understanding of pen-

\footnotetext{
${ }^{4}$ For a review, see Autor and Duggan (2006) and Wise, ed (2012).
} 
sions reforms also in other contexts. Second, the Austrian labor market is characterized by a very low labor force participation of older workers. In 2009, only 42 percent of individuals aged 55-64 were employed or looking for a job compared to an average of 57 percent in the OECD countries. The low labor force participation rate of older individuals in Austria is partly due to the low ERA but also due to the availability of alternative pathways into early retirement. Since a quite large fraction of the labor force of older workers is inactive and since the public pension system is quite generous, we expect the impact in the Austrian case to be quite large (compared to countries where the older labor force is better utilized and where the public pension system offers lower earning replacement rates). Austrian estimates may thus serve as an upper bound for effects of ERA-increases on labor market behavior of older workers. Finally, we can exploit the Austrian social security administration database (ASSD) that covers the universe of all private sector workers. The ASSD does not only report the complete employment- and earnings-history of these workers, it also informs about take-up of other welfare benefits (such as unemployment and disability benefits). Hence, we can study not only the labor market consequence but also the distributive effects of fiscal adjustment of the ERA-increase in a clean way.

To identify the effect of the ERA on labor market behavior of older workers we exploit the fact that the ERA-increase was phased in gradually implying that month-of-birth is the key determinant for the age of first eligibility for retirement benefits. As the ASSD reports the individuals' birth month, we can precisely determine each individual's ERA and hence estimate the effects of the ERA-increase by comparing the labor market behavior of younger birth cohorts to older birth cohorts who were not affected by the rise in the ERA.

Our empirical analysis yields the following results. First, we find (unsurprisingly) that an increase in the ERA leads to a substantial delay in retirement. However, the delay in retirement was not fully compensated by corresponding increases in employment. Our estimates indicate that increasing the ERA by one year reduces retirement benefit claims during that year by 18.9 percentage points among men and by 22.3 percentage points among women. The drop in retirement benefit claims is accompanied by an increase in employment of merely 6.8 percentage points among men and 10.1 percentage points among women. While this latter result indicates positive and non-negligible employment effects, it 
also shows that an even larger share of workers (who had to delay their retirement), spent this time in some form of non-employment.

Second, a closer look on take-up of welfare benefits shows that increasing the ERA causes a substantial increase in registered unemployment, 10.1 percentage points among men and women. The increase the percentage on disability benefits (and the percentage out-of-thelabor-force) is comparably small in magnitude. Hence, the caveat that increasing the ERA may lead to substantial spillovers to other welfare programs is quantitatively important in the Austrian case.

Finally, we explore the fiscal and distributive consequences of increasing the ERA. We do not find strong support for the claim that unhealthy low-wage workers bear most of the costs of the ERA-increase. To the contrary, we find that more than two thirds of the net reduction in government expenditures were generated by healthy individuals with lifetime incomes above the median. Fiscal effects generated by unhealthy individuals are small either because they retire through the disability system (the rules of which remained unchanged) or because they bridged the gap to later retirement by drawing unemployment benefits.

Our paper is related to an extensive literature studying how changes in benefit generosity affect the timing of retirement (Burtless, 1986; Krueger and Pischke, 1992; Börsch-Supan and Schnabel, 1998; Coile and Gruber, 2007; Liebman et al., 2009; Manoli and Weber, 2010). Those studies typically find that changes in retirement benefits have a significant impact on the timing of retirement. In contrast, there is little work on how a rise in the retirement age affects labor force participation.

Earlier studies have relied on out-of-sample predictions to estimate the labor supply response to changes in the ERA and NRA and typically find that a raise in the retirement age leads to a sizeable increase in labor force participation of older workers (Rust and Phelan, 1997; Panis et al., 2002; Gruber and Wise, eds, 2004). More recently, Mastrobuoni (2009) exploits a policy change in the U.S. that increased the NRA from 65 to 67 and raised the penalty for claiming retirement benefits before the NRA. He concludes that an increase in the NRA by 2 months delays effective retirement by around 1 month. This estimate is much larger than the effect suggested by the previous simulation studies, possibly because 
the out-of-sample projections omit factors that are important for the timing of retirement such as social custom or liquidity constraints.

Our paper estimates the labor supply response of an increase in the ERA as opposed to the NRA. This distinction is important for two reasons. First, an increase in the ERA forces individuals to claim retirement benefits later (or seek benefits from other sources) while an increase in the NRA is equivalent to a reduction in benefits. Second, the documented peak in the age distribution at retirement is typically more pronounced at the ERA as opposed to the NRA (Gruber and Wise, eds, 1999). Therefore, a rise in the ERA is likely to be a more effective measure to increase labor force participation among older workers as opposed to a rise in the NRA.

This paper also builds on a growing literature that explores how changes in the generosity of one social insurance program affects enrollment in other programs. Most of these studies focus on spillover effects of changes in the disability insurance (Autor and Duggan, 2003; Karlström et al., 2008; Borghans et al., 2010; Staubli, 2011) or unemployment insurance (Bloemen et al., 2011; Inderbitzin et al., 2011). The most closely related paper is Duggan et al. (2007) who study the same policy change as Mastrobuoni (2009) and find that the increased penalty for claiming retirement benefits before the NRA led to more disability insurance enrollment prior to the NRA. Our findings suggest that the increase in the ERA had a relatively small effect on disability recipiency. Instead we find that a significant fraction of affected individuals responded to the increase in the ERA by claiming unemployment benefits or staying in employment longer.

This paper proceeds as follows. Section 2 describes Austria's social insurance programs and the policy changes in the public pension system. Section 3 summarizes the data and presents descriptive statistics. Section 4 outlines the identification strategy. Section 5 presents the empirical results. Section 6 explores the implications of the reforms on net government expenditures. Section 7 draws conclusions. 


\section{Background}

\subsection{The Public Pension System in Austria}

The Austrian pension system covers almost all workers in Austria and provides early retirement pensions, old age pensions, and disability pensions. All pensions are subject to income taxation and mandatory health insurance contributions. Early retirement and old age pensions are the main source of retirement income and replace on average 80 percent of the most recent gross wage up to maximum of approximately 2,900 euros per month. Conditional on having 35 contribution years or 37.5 insurance years, early retirement pensions can be claimed at any age after 60 for men and 55 for women, though at a reduced rate. Insurance years comprise both contributing years (periods of employment, including sickness, and maternity leave) and qualifying years (periods of unemployment, military service, or secondary education). Old age pensions can be claimed at the NRA of 65 for men and 60 for women as long as the individual has 15 insurance years in the last 30 years or 15 contribution years.

The level of early retirement and old age pensions depends on the assessment basis and the pension coefficient. The assessment basis corresponds to the average earnings over the best 15 years after applying a cap to earnings in each year. The pension coefficient is the percentage of the assessment basis that is received in the pension. The pension coefficient increases with the number of insurance years up to a maximum of 80 percent (roughly 45 insurance years). Since 1996 there is a penalty for claiming benefits before the NRA and a bonus for retirement after the NRA of approximately 2 percentage points per year.

To be eligible for disability pensions, applicants must suffer a health impairment that will last for at least 6 months and must have accumulated at least 5 insurance years. Because medical criteria for disability classification are relaxed starting at age 57, disability pensions have played an important role in early retirement (Staubli, 2011). More specifically, below that age threshold, an individual is generally considered disabled if the capacity to work is reduced by more than 50 percent in any occupation in the economy. Above the age threshold of 57 the same individual qualifies for benefits if the work capacity is reduced by 50 percent in the same occupation. Because men first become eligible for early retirement pensions at age 60 as opposed to 55 for women, disability enrollment is disproportionately 
high among older men. In 2010, for example, 66 percent of new male recipients and 30 percent of new female recipients were older than 57. The calculation of disability pensions is identical to that of early retirement and old age pensions, except for a special increment that is granted to applicants below age 57 .

In January 2000 the Austrian government introduced a partial retirement scheme, allowing for a gradual transition from work to retirement. Conditional on having worked for 15 years in the past 25 years, male workers older than 55 and female workers older than 50 can reduce their working time to 40-60 percent of their previous work hours for a maximum period of five years while their earnings are only reduced to 70-80 percent. The scheme provides a great flexibility in scheduling work hours. In particular, workers are allowed to block their work hours within the agreed period. For example, a male worker who agreed to reduce his work hours by 50 percent can choose to work full time during the first 2.5 years of the program and effectively retire at age 57.5.

Unemployment benefits are not taxed and replace around 55 percent of the last net wage. Depending on the previous work history, unemployment benefits can be claimed for up to one year. Individuals who exhaust their regular unemployment benefits may apply for unemployment assistance. These means-tested transfers last for successive periods of 39 weeks after which eligibility requirement are recurrently checked and can be at most 92 percent of regular unemployment benefits. Unemployment insurance plays an important role in the transition to early retirement in Austria. Many older workers stop working before the eligibility age for an early retirement pension and bridge the gap via unemployment insurance benefits.

\subsection{The 2000 and 2003 Pension Reforms}

To improve the fiscal health of the public pension system, the Austrian government enacted the 2000 pension reform on October 1st 2000. The reform was debated in Parliament in June 2000 and approved at the beginning of July. The most important change was an increase in the eligibility age for early retirement pensions by 1.5 years for men and women. This increase was phased-in gradually over time. More specifically, each quarter of birth the eligibility age was raised by 2 months for men born after September 1940 and women 
born after September 1945 until reaching 61.5 for men born after September 1942 and 56.5 for women born after September 1947. Men with at least 45 insurance years (around $15 \%$ of 60-61.5 year old men) and women with at least 40 insurance years (around 10\% of 55-56.5 year old women) were unaffected by the increase in the eligibility age.

Along with this change, the Austrian government temporarily extended the maximum duration of unemployment benefits from 1 to 1.5 years. The extension of unemployment benefit was limited to a small group of people. Only men born between 1940 and 1942 and women born between 1945 and 1947 who had worked at least 15 years in the past 25 years and were unemployed in July 2000 or became unemployed after July 2000 were eligible. The benefit extension was in effect until December 2002. The reform also increased the penalties for retirement before the NRA and the bonus for retirement after the NRA. Specifically, before the reform each year of retirement prior to the NRA reduced the pension coefficient by 2 percentage points. After the reform this number was increased to 3 percentage points. The 2000 reform also extended the maximal duration of the partial retirement scheme from 5 to 6.5 years. This increase allowed for a smooth transition from partial retirement to regular retirement while leaving the minimum age to enter the partial retirement scheme unchanged at 55 for men and 50 for women.

In June 2003 the Austrian government enacted the 2003 pension reform, which became effective on January 1, 2004. The reform continued the increase in the eligibility age for early retirement pensions from 61.5 to 65 for men and from 56.5 to 60 for women. This increase was phased in gradually and occurred in two main stages. Each quarter of birth the eligibility age increased by two months for men born between January and June 1943 and women born between January and June 1948, followed by one-month increments per quarter of birth for men born between July 1943 and December 1952 and women born between July 1948 and December 1957. As for the 2000 pension reform, men with at least 45 insurance years and women with at least 40 insurance years were unaffected by the increase in the eligibility age for early retirement pensions.

The reform also reduced the generosity of benefits by lowering the pension coefficient and increasing the penalty for claiming a pension prior to the NRA. Specifically, before the reform each insurance year replaced 2 percent of the assessment basis. After the reform this 
number was lowered to 1.88 percent. Moreover, the reform changed the assessment basis from the best 15 years to the best 40 years. This extension is being phased-in between 2004 and 2028 and will decrease pension benefits, because the calculation of the assessment basis includes also years with low wages. Unlike the 2000 pension reform, there was no temporary extension of unemployment benefits.

Because the 2003 pension reform will eliminate the possibility to claim retirement benefits prior to the NRA, the Austrian government introduced the "corridor pension" on January 1,2005 . This pension is comparable to an early retirement pension and can be claimed between the ages of 62 and 65 , conditional on having 37.5 insurance years. (It essential allows early retirement at age 62, even when the regular ERA is higher.) Since the female NRA will be gradually increased from 60 to 65 beginning of 2024, for women the corridor pension will only be relevant after 2028. Until then, women can still claim an old age pension prior to age 62 .

\section{Figure 1}

Figure 1 summarizes the changes in the ERA for men born in January 1940 to September 1947 (left panel) and for women born in January 1945 to September 1952 (right panel). For these birth cohorts the eligibility age for an early retirement pension was increased between 2000 and 2010, which is the time period covered by our data. For older birth cohorts the eligibility age for an early retirement pension was increased in two-month increments, followed by one-month increments for younger birth cohorts. Over this time period the ERA for women was raised by a total of 39 months (3.25 years). Due to the introduction of the corridor pension, the increase in the ERA for men was 24 months (2 years).

The consequences of the increase in the ERA are seen in Figure 2, which plots the age distribution of retirement entry of men (left panel) and women (right panel) in 2000 and 2010. As the Figure illustrates, in 2000 retirement entry peaked at age 60 for women and age 55 for women. In 2010, the inflow rate for men at age 60 declined by almost 20 percentage points and increased by roughly 15 percentage points at age 62 . There are also smaller increases in the inflow rate at ages 63 and older. For women retirement entry at age 55 declined by roughly 35 percentage points in 2010 compared to 2000 and increased by more than 10 percentage points at age 58 . 


\section{Data and Descriptives}

To examine the impact of the increase in the ERA on labor market behavior, we use data from the Austrian Social Security Database (ASSD), which is described in Zweimüller et al. (2009). The data contain very detailed longitudinal information dating back to 1972 for all private sector workers in Austria. For all individuals who have retired by the end of 2010, information on insurance relevant states is available for the years prior to 1972. At the individual level the data include gender, nationality, month and year of birth, blue-collar or white-collar status, labor market history, earnings and individual identifiers. The data contain several firm-specific variables: geographical location, industry affiliation and firm identifiers (from 1972 onward) that allow us to link both individuals and firms.

Our main sample consists of all men aged 60-62.25 with less than 45 insurance years and women aged 55-58.5 with less than 40 insurance years over the period 1996 to 2010 (men born in January 1935 to September 1950 and women born in October 1938 to September 1955). Given the introduction of the partial retirement scheme in January 2000 with the potential to affect labor market behavior, the analysis focuses primarily on the years 2000 to 2010. The sample restrictions are as follows. From the initial sample of 496,170 men and 520,486 women, we exclude 77,802 men with more than 45 insurance years and 43,954 women with more than 40 insurance years. We also exclude 18,222 men and 14,840 women who spent any time as civil servants, as they are covered by a separate pension system with different eligibility rules. We also exclude 28,924 men and 22,966 women who have spent any time working in jobs defined as heavy labor, as they might be eligible for a special heavy labor pension. The final sample thus comprises 371,222 men and 438,726 women.

Individuals are observed on the $1^{\text {st }}$ of January, $1^{\text {st }}$ of April, $1^{\text {st }}$ of July, and $1^{\text {st }}$ of October in each year. Due to the phase-in of the 2000 and 2003 policy changes, the age at which someone can claim retirement benefits is a function of the month and year of birth. Since this information is contained in the data, we can determine exactly who is eligible for retirement benefits in a given quarter. The earliest start date for retirement benefits is

the first of the month after reaching the ERA. For example, individuals who start claiming 
retirement benefits on October 1, 2000, have reached the ERA in September 2000 or earlier.

Tables 1 presents summary statistics by year for men aged 60-62.25 and women aged 55-58.5. As shown in Panel A, from 2000 to 2010 there have been dramatic changes in the fraction of men and women in different labor market states. Over this time period the share of individuals claiming retirement benefits decreased from 34.2 to 10.2 percent among men and from 49.4 to 7.2 percent among women. This decline was accompanied by a significant rise in employment from 8 to 29.5 percent among men and from 26 to 56.1 percent among women. However, there is also evidence that the rise in the ERA increased registered unemployment. ${ }^{5}$ From 2000 to 2010 the unemployment rate rose by 7.5 percentage points among men and 6.2 percentage points among women. Similarly, there is 3.2-4.4 percentage points increase in the share of individuals who are not in the labor force. Over the same period disability enrollment declined among men and remained roughly constant among women, perhaps reflecting the impact of the reduction in the generosity of disability and retirement benefits that was part of the 2000 and 2003 policy reforms. The share of individuals in the partial retirement program is very low and has increased by only 0.5 percentage points from 2000 to 2010 .

Panel B shows the characteristics of our sample in 2000 and 2010. Both for men and women there are only minor differences in observable characteristics between these two years. Women are less likely to work in blue-collar occupations and tend to have more sick leave days than men. They also tend to have less work experience and less insurance years than their male counterparts. These differences largely arise because women in our sample are on average five years younger than men. Finally, the last two rows of Panel B show that annual and average earnings of women are roughly one third below annual and average earnings of men.

\section{Table 1}

To illustrate the impact of the increase in the ERA graphically, Figure 3 plots trends in retirement, employment, and other states (defined as not being employed or retired) over time among men aged 60-62 and women aged 55-58.25. As Panel A of Figure 3 illustrates,

\footnotetext{
${ }^{5}$ Unemployment is defined here as being registered at an unemployment office, without necessarily receiving regular unemployment benefits or unemployment assistance.
} 
in the years before the 2000 reform became effective approximately 35 percent of men and 50 percent of women claimed retirement benefits. The fraction is higher among women because many men already withdraw from the labor market before age 60 by applying for disability benefits. After 2000 the fraction of retired men aged 60-62 decreased by almost 30 percentage points up to 2005 and then stays fairly constant. In 2005 the corridor pension was introduced, which allowed men to permanently retire at age 62 . Similarly, there is a 45 percentage points decline in the share of 55-58.25 year old women in retirement. The figure also illustrates that in 2010 small share of men and women still claim retirement benefits prior to the new ERA of 62 for men and 58.25 for women, which is most likely due to some measurement error in the calculation of insurance years.

\section{Figure 3}

The drop in retirement benefit claiming was accompanied by a large increase in employment of 20 percentage points among men and 30 percentage points among women (Panel $\mathrm{B}$ of Figure 3). ${ }^{6}$ As Panel $\mathrm{C}$ of Figure 3 shows, evidence for the other states is mixed. To explore the labor market effect further, Figure 4 groups the category other states into the subcategories unemployment, disability, and not in the labor force. Panel A of Figure 4 shows that after 2000 there is a substantial increase in the unemployment rate, while disability enrollment declined among men and stayed fairly constant among women (Panel B of Figure 4). As Panel $\mathrm{C}$ of Figure 4 illustrates, there is also an increase in the fraction of individuals not in the labor force. Of course, part of the documented trends in Figures 3 and 4 could simply reflect the impact of changes that are unrelated to the increase in the ERA. To separate the impact of the increase in the ERA from macroeconomic and other common factors, we compare labor market trends of younger and older birth cohorts over time, as outlined in the next section.

\section{Figure 4}

\footnotetext{
${ }^{6}$ Employment as it is defined here also includes individuals enrolled into the partial retirement program. Since the size of the partial retirement program is small, excluding these individuals has virtually no impact on employment trends.
} 


\section{Identification Strategy}

The goal of the 2000 and 2003 reforms was to foster employment among older workers by increasing the ERA. While access to retirement benefits became stricter as a result of this increase, eligibility criteria for unemployment, partial retirement, and disability benefits remained the same. Therefore, it is plausible that some individuals who would have otherwise claimed retirement benefits responded to this change by seeking benefits from other social insurance programs. Such a change in behavior would diminish the positive effect of these reforms on employment.

Because the increase in retirement age was phased-in gradually, the age at which an individual could claim retirement benefits depended on the month of birth. For example, men born before October 1940 could claim benefits at age 60 while those born in October to December 1940 had to wait 2 months longer before they became eligible for benefits. As illustrated in Figure 1, there are similar discontinuities in the ERA for other birth cohorts and for women. On this basis, the primary approach to estimate the effect of the rise in the retirement age compares the labor market behavior of younger birth cohorts to older birth cohorts who were not affected by the increase in the ERA.

This comparison can be implemented by estimating regressions of the following type:

$$
y_{i t}=\alpha+\theta_{i}+\lambda_{t}+X_{i t}^{\prime} \beta+\gamma \text { Below }_{i t}+\varepsilon_{i t}
$$

where $i$ denotes individual, $t$ quarter, and $y_{i t}$ is the outcome variable of interest; $\theta_{i}$ are age fixed effects (where age is measured in months) to control for age-specific trends in labor market behavior; $\lambda_{t}$ is a set of quarter fixed effects to capture common time shocks in labor market behavior; and $X_{i t}$ represents individual or region specific characteristics to control for any observable differences that might confound the analysis (blue-collar status, experience, insurance years, sick days, previous annual earnings, average earnings over the best 15 years, industry dummies, region dummies, and a fourth-order polynomial in birthmonth to control for cohort-varying outcome characteristics).

The key explanatory variable is Below, which is equal to one if an individual's age in quarter $t$ is below the ERA, and zero otherwise. For example, because the first increase in 
the ERA occurred in the forth quarter of 2000, Below is zero for all individuals on January 1, April 1, July 1, and October 1, 2000. On January 1, 2001, Below is one for men below age 60.17 born in October to December 1940 and women below age 55.17 born October to December 1945, because for these birth cohorts the ERA was increased by 2 months in the forth quarter of 2000 .

The identifying assumption is that, absent the increase in the ERA, the change in $y_{i t}$ would have been comparable between age groups not yet eligible for retirement benefits (treatment group) and those eligible (comparison group) after controlling for background characteristics. Under this assumption, $\gamma$ measures the average causal effect of an increase in the ERA on $y_{i t}$, using variation over time. Equation (1) is estimated separately for men aged 60-62.25 and women aged 55-58.5 using data for the period 2000 to 2010. The advantage of focusing on a small age range is that individuals who are not affected by the increase in the retirement age are close substitutes to those affected. Thus, trends in labor market behavior across age groups are likely to be similar. As a placebo test, we estimate equation (1) for the period 1996 to 2000 assuming that the increase in the ERA started in the forth quarter of 1996; during this time period the ERA remained effectively unchanged, and so we expect $\gamma$ to be zero.

Both the 2000 and 2003 pension reforms implemented other changes to the pension system, in addition to the increase in the ERA. A potential concern of our empirical strategy is that theses changes had a differential impact on the labor market behavior in the treatment and comparison groups. Both the 2000 and 2003 pension reforms raised the penalty for claiming retirement benefits before the NRA. The reduction in the pension coefficient was relatively modest and is unlikely to have affected retirement behavior in the treatment and comparison groups differently. For example, the 2000 pension reform reduced the retirement benefits of a 62 year old men by 3 percentage points. The penalty implemented with the 2003 reform was even smaller. To investigate the impact of the reduction in benefit generosity, we re-estimate equation (1) with age-specific time trends, to allow treatment and comparison age groups to follow different trends.

The 2000 pension reform also temporarily extended the duration of unemployment benefits from 1 to 1.5 years for men born between 1940 and 1942 and women born between 
1945 and 1947 who had worked at least 15 years in the past 25 years. This extension may affect the employment response if eligible individuals respond to the increase in the ERA by seeking unemployment benefits instead of remaining in employment. However, since the extension was limited to a small group of people and only effective for a short period of time, it is unlikely to have a large effect on the estimates.

\section{Figure 5}

To illustrate the idea behind the identification strategy graphically, Figure 5 plots trends in retirement, employment, and other states for men between the ages 58 and 64 by birth cohort. The vertical lines represent the cohort-specific ERA as implemented by the 2000 and 2003 policy changes. As shown in Panel A, the fraction of men who claim retirement benefits increases by 20 to 25 percentage points at the ERA. The increase in retirement benefits claiming at the ERA is accompanied by a drop in employment of 10 percentage points. Similarly, the fraction of men enrolled in other states declines by almost 15 percentage points at the ERA. However, for younger birth cohorts the declines in employment and enrollment in other states occur later in life due to the increase in the ERA.

\section{Figure 6}

Figure 6 shows trends for three subcategories of other states (unemployment, disability, and not in the labor force) by age for men born in different months. Panel A shows that a sizeable share of men is unemployed before claiming retirement benefits. Because of the increase in the ERA, younger birth cohorts tend to stay unemployed longer than older birth cohorts. On the other hand, as Panel B illustrates, the increase in the ERA had little effect on disability enrollment. Similarly, the fraction of individuals not in the labor force differs only slightly across birth cohorts, as shown in Panel C.

\section{Figure 7}

Figures 7 and 8 present labor market trends for women between the ages 53 and 59 by birth cohort. As shown in Panel A of Figure 7, the fraction of women claiming retirement benefits rises by around 30 percent at the ERA, although the effect is somewhat smaller for the youngest birth cohort. Panel B of Figure 7 suggests that a significant share of women 
responded to the policy change by staying in employment as for younger birth cohorts the drop in employment occurs at a later age. As for men, Panel A of Figure 8 shows that due to the increase in the ERA, younger birth cohorts tend to stay unemployed longer than older birth cohorts. On the other hand, the increase in the ERA had virtually no effect on the probability of receiving disability benefits (Panel B of Figure 8) or on the probability of being out of the labor force (Panel $\mathrm{C}$ of Figure 8). These figures are consistent with the hypothesis that the rise in the ERA increased employment among men and women, but had also important spillover effects into other social insurance programs, primarily the unemployment insurance. In the next section, we quantify the magnitude of these effects by using the model in equation (1).

\section{Figure 8}

\section{Effects of the ERA-increase on labor market behavior}

We are now ready to present our empirical results on the impact of the ERA increase on labor market behavior. We proceed in two steps. We first focus on the impact on retirement and employment, treating all other states as residual category. We then proceed by a closer focus on how the ERA-increase affected enrollment into other welfare state programs, in particular take-up of unemployment and disability benefits.

\subsection{Impact on Retirement and Employment}

Table 2 present OLS estimates on the impact of the policy change on retirement benefits claiming, employment, as well as other states of non-employment. The dependent variable $y_{i t}$ is a dummy, which is equal to 1 if an individual is in the state in question and 0 otherwise. Columns 1 through 4 provide estimates of our key explanatory variable Below for men and columns 5 through 8 display analogous results for women.

Column 1 of Panel A indicates that the increase in the ERA reduced retirement benefits claiming among affected men by 20.76 percentage points, or 60.6 percent of the baseline retirement rate of 60-62.25 year old men in 2000. Column 1 of Panel B shows that this decline was accompanied by an increase in employment of 6.95 percentage points. The total effect on employment is even larger, when partial retirement is included (column 1 of Panel 
C). At the same time, the share of affected men enrolled in other states increased by 12.33 percentage points, as illustrated in column 1 of Panel D.

Column 2 of Table 2 indicates that adding control variables to equation (2) has only minor effects on the estimates. These estimates will be biased if the treatment and comparison groups have different labor supply tendencies. To shed light on this concern, we add age-specific time trends to the baseline specification. The implied estimates are largely insensitive to these additional controls, as illustrated in column 3 of Table 2. Column 4 shows estimates if we restrict attention to the period 1996 to 2000 assuming (incorrectly) that the increase in the ERA started in the forth quarter of 1996. Although some coefficients are significant, the magnitude is small, suggesting that our estimation strategy is not simply picking up long-run trends in differences across age groups.

Turning to the results for women, column 5 of Panel A demonstrates that the increase in the ERA reduced retirement benefits claiming among affected women by 22.96 percentage points. This decline amounts to 52.3 percent of the baseline retirement rate among 55-58.5 year old women in 2000. As shown in column 5 of Panel B, one direct consequence of the decline in retirement benefits claiming was an increase in employment of 9.72 percentage points. As for men, the increase in employment is larger when partial retirement is included (column 5 of Panel C). Similarly, as illustrated in column 5 of Panel D, there is a 10.29 percentage points increase in the share of women enrolled in other states. The results are very similar for the various specifications such as adding individual characteristics (column 6) and controlling for age-specific time trends (column 7). Column 8 presents estimates if we restrict the sample to the period 1996 to 2000. Some coefficients are significant, but they are all small in size.

\section{Table 2}

\subsection{ERA-effects on other Welfare Programs}

To explore the labor market effects of the increase in the ERA in more detail, we group individuals that are enrolled in other states in three subcategories (unemployment, disability, and not in the labor force) and then estimate equation (1) for each subcategory separately (Table 3). Columns 1 through 4 report coefficient estimates of our key explanatory variable 
Below for men and the next four columns display the analogous estimates for women.

Consistent with the graphical analysis, column 1 of Panel A shows that registered unemployment increased by 10.5 percentage points among affected men. On the other hand, the increase in the ERA had little impact on disability enrollment, as shown in Panel B. The low disability response stands in contrast with Duggan et al. (2007) who find that the rise in full retirement age in the U.S. significantly increased disability insurance enrollment. One possible explanation for the low disability response is that applications for disability benefits are screened more rigourously after the increase in the ERA. Therefore, disability enrollment varies little even though individuals may be more likely to seek benefits. ${ }^{7}$ Column 1 of Panel $\mathrm{C}$ indicates that this policy change increased the share of men that is not in the labor force by 1.37 percentage points. Columns 2 and 3 show that these results are very robust to different specifications. Column 4 illustrates that the coefficient estimates are largely insignificant if we restrict the sample to the time period 1996 to 2000 .

Turning to the results for women, column 5 of Panel A illustrates that, as for men, the rise in the ERA led to a substantial increase in registered unemployment of 8.46 percentage points and had virtually no effect on disability enrollment (column 5 of Panel B). This policy change also led to a small increase the share of women who are not in the labor force, as column 5 of Panel $\mathrm{C}$ demonstrates. Adding control variables leads to a larger estimate of the increase in the ERA on registered unemployment (columns 6 and 7 of Panel A). As for men, column 8 illustrates that the estimates are small in size and insignificant if we restrict attention to the period 1996 to 2000 and assume that the increase in the ERA started in the forth quarter of 1996.

\section{Table 3}

The effects shown in Tables 2 and 3 can result either from changes in the inflow into a certain state, or changes in the persistence in a certain state, or both. To shed light on the importance of these two effects, Table 4 reports estimates from equation (1) for transitions from and persistence in employment and unemployment. We focus on these two states because they were affected most by the increase in the ERA. Column 1 of Panel A

\footnotetext{
${ }^{7}$ It is impossible to examine the reforms' impact on applications for disability benefits because this information is not recorded in the data.
} 
suggests that among men the increase in the ERA reduced direct exits from employment into retirement by 20.69 percentage points. This decline was almost entirely compensated by a one to one increase in employment persistence, as illustrated in column 2 of Panel A. On the other hand, columns 3 to 6 of Panel A indicate that this policy change had only minor effects on transitions from employment into unemployment, disability, partial retirement, or out of labor force. Panel B summarizes the results for transitions from and persistence in unemployment among men. As column 1 of Panel B demonstrates, there is a sizeable decline in transitions from unemployment to retirement by 74.23 percentage points. As in the case of employment, the decline in retirement benefits claiming was absorbed by an increase in unemployment persistence (column 3 of Panel B), while leaving transitions to other exit states largely unaffected.

The analogous estimates for women are summarized in Panels C and D of Table 4. The estimated decline in transitions from employment to retirement of 8.5 percentage points summarized in column 1 of Panel $\mathrm{C}$ is half as large as the corresponding estimate for men. As for men, the rise in the ERA increased persistence in employment by 7.81 percentage points but had no effect on transitions to other states. The estimates in Panel D illustrate that the increase in the ERA reduced the probability of a transition form unemployment to retirement (column 1) and increased the persistence in unemployment (column 3).

\section{Table 4}

Because disutility of work may increase over age, it is instructive to examine how the effect of this policy change varies by age. This analysis can be implemented by interacting Below with a series of indicators for whether an individual's age is in a certain range. OLS estimates of equation 1 for different age groups are provided in Table 5.

Columns (1) and (4) show that this policy change was much more effective in reducing retirement benefits claiming at younger ages compared to older ages. One possible explanation is that if the ERA is higher, individuals have more time to accumulate insurance years. Thus, individuals are more likely to be exempted from the increase in the ERA. Columns (2) illustrates that the rise in the ERA increased male employment in all age groups, but the magnitude is almost twice as large for the youngest age group compared to the oldest age group. A similar age pattern can be observed for female employment, although the 
difference between the youngest and the oldest age group is less pronounced than for men. The estimates in columns (3) and (6) illustrate that approximately 50 percent of the decline in retirement was compensated by an increase in registered unemployment, although in absolute terms the effect is larger for younger ages compared to older ages. The increase in the ERA from 60 to 61.5 for men and from 55 to 56.5 for women was accompanied by a temporary extension of unemployment benefits from 1 to 1.5 years. The constant relative increase in registered unemployment across age groups suggests that the temporary extension of unemployment benefits had a negligible impact on behavior.

\section{Table 5}

\section{The Distributive Implications of the ERA-increase}

In this section we study the distributional consequences of the Austrian pension reform. We first look whether and to what extent workers' responses to an increase in the ERA are heterogenous. There are two dimensions of heterogeneity across individuals that are of particular interest in the present context: health and income. Intuitively, we do not only want to know whether high- or low-wage workers contributed most to the net savings on social security expenditures but also whether the healthy individuals are more strongly affected than the less healthy. We then translate the estimated effects into changes in government expenditures (taking account of increases in taxes and social security contributions for those workers that stay longer in employment and of increase in transfers other than retirement benefits for those who enter some other welfare program).

\subsection{Heterogeneity in ERA-effects}

Previous studies have documented that health (e.g., Rust and Phelan, 1997; Blau and Gilleskie, 2001) and past earnings (e.g. Bound et al., 2010) are important determinants of the retirement decision. To examine how these factors interact with the policy changes, Table 6 reports OLS estimates of equation (1) by health and lifetime earnings for men. Table 7 reports analogous estimates for women. Lifetime earnings here are measured by the average earnings of the best 15 years. Health is measured by the time spent in sick leave prior to age 54. An individual is considered "healthy" if the time spent on sick leave 
prior to age 54 is below the median. Individuals with sick leave days above the median are defined as "unhealthy".

Interestingly, as shown in Table 6, among men the decline in retirement is more pronounced for the healthy. Moreover, healthy individuals react more strongly to the ERAincrease the higher their lifetime income. Among those in the fourth quartile of the lifetime earnings distribution, the ERA-increase reduces retirement benefit claims by as much as 31.9 percentage points compared to only 17.4 percentage points among those in the first quartile. The income gradient of the ERA effect is flatter among the unhealthy, although also among them the strongest impact is among those with the highest lifetime income. Similarly, the ERA-effect on employment is stronger among the healthy and stronger for high-wage workers than for low-wage workers.

The situation is somewhat different for women (Table 7). On the one hand, there is a positive income-gradient of the ERA-effects, i.e. high-wage females react more strongly to the ERA-increase than low-wage females. On the other hand, less healthy women delay their retirement more strongly than the more healthy. Why does the health-gradient differ between females and males? The difference is attributable to disability pension rules. Both males and females have relaxed access to disability benefits at age 57. Due to this rule men but not women have the relaxed access to disability benefits prior to the ERA (recall that the ERA of females is 5 years lower than the one for males). While many less healthy males have already left the labor force before the ERA through relaxed access disability benefits, many less healthy females have to stay in the labor force because relaxed disability benefits are not yet available to them. Notice also the differential ERA-effects on employment and unemployment between healthy and unhealthy females. Comparing the relative size of retirement coefficient (Panel A) to employment and unemployment coefficients (Panels B and $\mathrm{C}$ ) reveals that delaying retirement is associated with longer employment for roughly 60 percent (ratio of employment to retirement coefficient in columns 1-4) and additional unemployment for roughly 25 percent (ratio of unemployment to retirement coefficients in columns 1-4). The corresponding ratios for the unhealthy are quite different: longer employment for only 30 percent, but longer unemployment for more than 50 percent.

\section{Table 6}




\subsection{Fiscal Implications}

The primary objective of the 2000 and 2003 pension reforms was to reduce expenditures of the public pension system by fostering labor force participation among older workers. The reforms effectively increased the ERA between 2000 and 2010 by 2 years among men and by 3.25 years among women. The results of the empirical analysis presented in the previous sections suggest that the reforms succeeded in reducing retirement inflow. However, delayed retirement did not lead to a one-for-one increase in employment. Instead, we find considerable spillover effects to unemployment insurance benefit claims and, to a lesser extent, to the disability insurance program.

Based on the above estimation results we can provide a rough estimate how the ERAincrease affected net government expenditures (see Table 8. The change in the number of individuals in different states is based on the estimates in Tables 6 and 7 that account for heterogeneity in ERA-effects by lifetime income and health status prior to the ERAincrease.

Our thought experiment is as follows. We quantify the yearly fiscal effects (effects on the government budget) by comparing males aged 60-62 in the pre-reform situation (when the ERA was age 60 ) to the post-reform situation (when the ERA had increased to age 62 ; and similarly for women aged 55-58.25. According to Panel A of Table 6 the share of $60-62$ year old men in retirement decreases by 17.4 percentage points for healthy workers in the first quartile of the lifetime income distribution, 20.5 percentage points for healthy workers in the second quartile of the lifetime income distribution, and so on. We then multiply these estimates with the average number of workers aged 60-62 in the various cells of the health/lifetime-income matrix; and with the average retirement benefits, income taxes and social security contributions, unemployment benefits and disability benefits for each cell in the matrix. This lets us calculate the absolute change in the number of workers in retirement, in employment, and on unemployment and disability benefits and the associated changes in government-expenditures and -revenues. For simplicity, our calculation assumes that other states of non-employment do not affect government expenditures. ${ }^{8}$

\footnotetext{
${ }^{8}$ Note that our calculation overestimates the absolute size of the reduction in government expenditures
} 
In Table 8 we show the overall fiscal implication of the ERA increase. The first column of Table 8 presents a hypothetical estimate for net government savings assuming that all reduction in early retirement claims were accompanied by the same increase in employment (i.e. assuming the complete absence of any spillover effects to other welfare programs). We find that the Austrian government would have saved 264 million Euros per year, if the observed reduction in early retirement claims would have be accompanied by a corresponding increase in employment without any spillover effects to other welfare programs. This estimate is equivalent to a reduction of $54.8 \%$ in net government expenditures on 60-62 year old men and 55-58.25 year old women (using pre-reform expenditures as the baseline).

How much of this hypothetical reduction in government expenditures does actually materialize? The remaining columns of Table 8 estimates the actual reduction in net government expenditures taking spillover effects into account. It estimates the impact of (i) the fiscal savings due to lower retirement benefit payments (second column); (ii) the increase in government revenues due to additional social security contributions and direct taxes paid by those who remain longer in employment (third column); (iii) higher government outlays for unemployment and disability insurance (fourth column). The final column reports the net change government expenditures, i.e. the overall fiscal impact of the ERA-increase. We find that the ERA-increase reduced retirement benefits payments by 157.5 million Euros; increased government revenues by 47.2 million Euros; and increased unemployment and disability benefit payments by 56.8 million Euros. In sum, the government saved 147.9 millions Euros or $30.1 \%$ of pre-reform net government expenditures on 60-62 year old men and 55-58.25 year old women. This shows that spillover effects are huge. Put differently, about 44 percent of potential government savings get lost due to spillovers effects.

Interestingly, more than 50 percent of the fiscal effect is generated by women. This is due to 2 reasons. First, women react more strongly to the ERA increase than men. And second, the number of affected women is larger because the relevant age-window where reactions take place is 3.25 years for women while it is only 2 years for men. Hence, despite the fact that retirement benefits, earnings and unemployment and disability benefits are lower for women, this is offset by the larger number of women who actually respond to the as some individuals may have access to other transfers (such as social welfare benefits) that we do not observe in our data. However, since the ERA-increase had a small impact on the share of individuals who are not in the labor force, the resulting bias is small. 
ERA-increase.

Finally, we quantify the distributive implications of the ERA-increase. We focus on the two interesting dimensions of heterogeneity: health status and lifetime income. Table 9 shows that, among men, 24.8 million or almost 40 percent of the fiscal impact is generated by the healthy rich (row 4, column 5) and almost 60 percent are generated by healthy males with lifetime income above the median. The contribution of unhealthy males is comparably small. The picture is somewhat different for women. The bulk of fiscal savings is generated by healthy workers with a lifetime income above the median (almost 50 percent). However, also unhealthy women (those with a lifetime income above the median) also generate substantial reductions in net government expenditures.

\section{Table 8}

In sum, Table 9 gives a mixed picture on the distributive consequences of the ERAincrease. On the one hand, the healthy, high-wage workers contribute most to the net reduction in government expenditures while than the less-healthy, low-wage workers are much less affected. On the other hand, women contribute more to government savings than men, despite the fact that they earn significantly less than men; and a larger share of the burden of fiscal adjustment is carried by the less healthy women. Notice, however, that the former effect is intended by the government, as an important part of the pension reform (that will fully materialize in the future) is to equalize retirement rules for males and females. This will also bring the health gradient among women closer to the one among men.

\section{Table 9}

\section{Conclusion}

Relying on two policy changes in Austria, this paper analyzed the impact of an increase in the ERA on the labor supply of older workers. Austria is characterized by a low labor force participation of older workers. Only 42 percent of men and 29 percent of women aged 55-64 are employed or actively seeking for work. With the goal of fostering employment and improving the fiscal health of the public pension system, in 2000 and 2003 the Austrian 
government implemented a series of changes to the public pension system. The most significant change brought about by this legislation was a gradual increase in the early retirement age from 55 to 58.25 for women and from 60 to 62 for men between 2000 and 2010 .

Using data on the universe of Austrian private sector workers, our empirical analysis suggests that an increase in the ERA has significantly delayed retirement. Specifically, retirement probabilities fell by 18.9 percentage points for males aged $60-62$; and by 22.3 percentage points for females aged 55-58.25. However, delayed retirement did not lead to a one-for-one increase in employment. Employment probabilities increased by 6.8 percentage points among men and by 10.1 percentage points among women. This suggests that among 100 workers who retire later, between 30 and 40 percent prolong their employment while between 60 and 70 percent are in some form of non-employment. Among the latter group, the majority draws unemployment benefits (unemployment probabilities increased by 10.1 percentage points for males and by 10.2 percentage points for females). The empirical analysis also suggests that an increase in the ERA had only a small effect on disability insurance claims.

Pensions reforms are hotly debated, not least because of their distributive consequences. Our analysis has shown that the net reduction in government expenditures are to a disproportionate extent generated by healthy individuals with incomes above the median. We conclude that Austrian pension reforms had some favorable distributive implications by letting high-wage and healthy workers carrying most of the burden of fiscal adjustment, while leaving poorer and less healthy largely unaffected. However, the Austrian pension reforms also lead to quite large spillover effects to unemployment insurance. Successful future pension reforms need to combine delayed retirement with stronger work incentives (for both firms and workers) to reduce spillover effects to other welfare programs and to generate higher employment rates for workers close to retirement.

Public pension programs are large and growing in most industrialized countries. Understanding how changes in the program parameters affect labor supply is extremely important for policy makers. One way to control the size and growth of public pension programs is through an increase in the ERA. The estimates presented in this paper suggest that this measure is effective in increasing employment, despite large absorption effects by the un- 
employment insurance. The Austrian labor market is characterized by relatively generous unemployment among older workers. Thus, the large increase in unemployment due to the ERA may partly reflect unfavorable labor market conditions among older workers. In a more flexible labor market, such as the one in the U.S., increasing the ERA is likely to generate a better ratio of employment and unemployment effects. 


\section{References}

Autor, David H. and Mark G. Duggan, "The Rise in the Disability Rolls and the Decline in Unemployment," Quarterly Journal of Economics, 2003, 118, 157 - 206.

_ and _ , "The Growth in the Social Security Disability Rolls: A Fiscal Crisis Unfolding," Journal of Economic Perspectives, 2006, 20 (3), 71-96.

Blau, D.M. and D.B. Gilleskie, "The effect of health on employment transitions of older men," in S. Polachek, ed., Worker Wellbeing in a Changing Labor Market. Research in Labor Economics, Vol. 20, JAI Press, Amsterdam, 2001.

Bloemen, Hans, Stefan Hochguertel, and Marloes Lammers, "Job Search Requirements for Older Unemployed: Transitions to Employment, Early Retirement and Disability Benefits," IZA DP, 2011, 544, 1-49.

Borghans, Lex, Anne C. Gielen, and Erzo F.P. Luttmer, "Social Support Shopping: Evidence from a Regression Discontinuity in Disability Insurance Reform," IZA DP No. 5412, 2010.

Börsch-Supan, Axel and Reinhold Schnabel, "Social Security and Declining LaborForce Participation in Germany," American Economic Review, 1998, 88 (2), 173-78.

Bound, John, Todd Stinebrickner, and Timothy Waidmann, "Health, economic resources and the work decisions of older men," Journal of Econometrics, 2010, 156, $106-129$.

Burtless, Gary, "Social Security, Unanticipated Benefit Increases, and the Timing of Retirement," The Review of Economic Studies, 1986, 53 (5), 781-805.

Coile, Courtney C. and Jonathan Gruber, "Future Social Security Entitlements and the Retirement Decision," The Review of Economics and Statistics, 2007, 89 (2), 234-246.

Duggan, Mark, Perry Singleton, and Jae Song, "Aching to Retire? The Rise in the Full Retirement Age and its Impact on the Social Security Disability Rolls," Journal of Public Economics, 2007, 91 (7-8), 1327-1350. 
Gruber, Jonathan and David A. Wise, eds, Social Security and Retirement around the World, University of Chicago Press, 1999.

_ and _, eds, Social Security Programs and Retirement Around the World: Micro Estimation, University of Chicago Press, 2004.

_ and _, eds, Social Security Programs and Retirement around the World: Fiscal Implications of Reform, University of Chicago Press, 2007.

Inderbitzin, Lukas, Stefan Staubli, and Josef Zweimüller, "Unemployment Insurance, Disability Insurance and the Early-Retirement Decision," mimeo, University of St. Gallen and University of Zurich, 2011.

Karlström, Anders, Marten Palme, and Ingemar Svensson, "The Employment Effect of Stricter Rules for Eligibility for DI: Evidence from a Natural Experiment in Sweden," Journal of Public Economics, 2008, 92, 2071-82.

Krueger, Alan B. and Jorn-Steffen Pischke, "The Effect of Social Security on Labor Supply: A Cohort Analysis of the Notch Generation," Journal of Labor Economics, 1992, $10,412-437$.

Liebman, Jeffrey B., Erzo F.P. Luttmer, and David G. Seif, "Labor supply responses to marginal Social Security benefits: Evidence from discontinuities," Journal of Public Economics, 2009, 93, 1208-1223.

Manoli, Dayanand and Andrea Weber, "Intertemporal Substitution in Labor Force Participation: Evidence from Policy Discontinuities," IZA DP No. 5248, 2010.

Mastrobuoni, Giovanni, "Labor supply effects of the recent social security benefit cuts: Empirical estimates using cohort discontinuities," Journal of Public Economics, 2009, 93, $1224-1233$.

OECD, "Pensions at a Glance 2011," Technical Report, Organisation for Economic Cooperation and Development 2011.

Panis, Constatijn, Michael Hurd, David Loughran, Julie Zissimopoulos, Steven Haider, and Patricia StClair, "The Effects of Changing Social Security Adminis- 
tration's Early Entitlement Age and the Normal Retirement Age," report for the SSA, RAND., 2002.

Rust, John and Christopher Phelan, "How Social Security and Medicare Affect Retirement Behavior In a World of Incomplete Markets," Econometrica, 1997, 65 (4), 781-831.

Schwarz, Anita M. and Asli Demirguc-Kunt, "Taking Stock of Pension Reforms Around the World," World Bank, Social Protection Discussion Paper Series 9917, 1999.

Staubli, Stefan, "The Impact of Stricter Criteria for Disability Insurance on Labor Force Participation," Journal of Public Economics, 2011, 95 ((9-10)), 1223Ü1235.

Wise, David A., ed., Social Security Programs and Retirement around the World: Historical Trends in Mortality and Health, Employment, and Disability Insurance Participation and Reforms, NBER Book Series - International Social Security, University of Chicago Press, 2012.

Zweimüller, Josef, Rudolf Winter-Ebmer, Rafael Lalive, Andreas Kuhn, JeanPhilippe Wuellrich, Oliver Ruf, and Simon Büchi, "Austrian Social Security Database," IEW - Working Papers Series No. 410, 2009. 

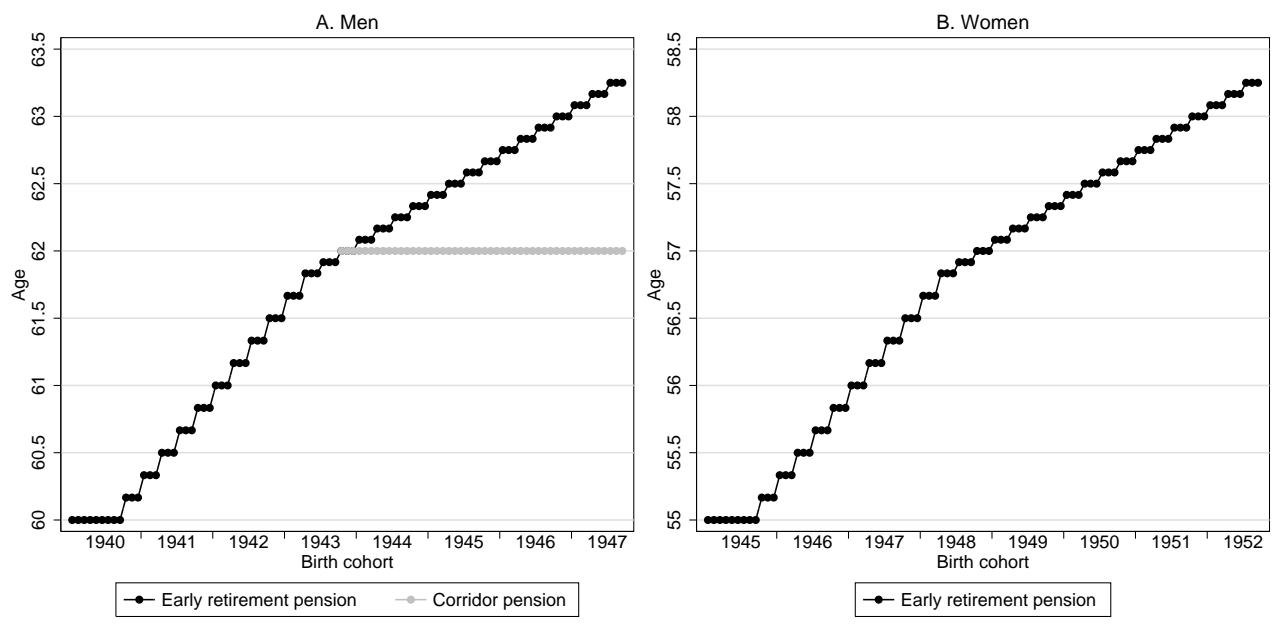

Figure 1: Increase in the minimum retirement age by gender. Source: Austrian federal laws (Bundesgesetzblätter) no. 92/2000, 71/2003. 

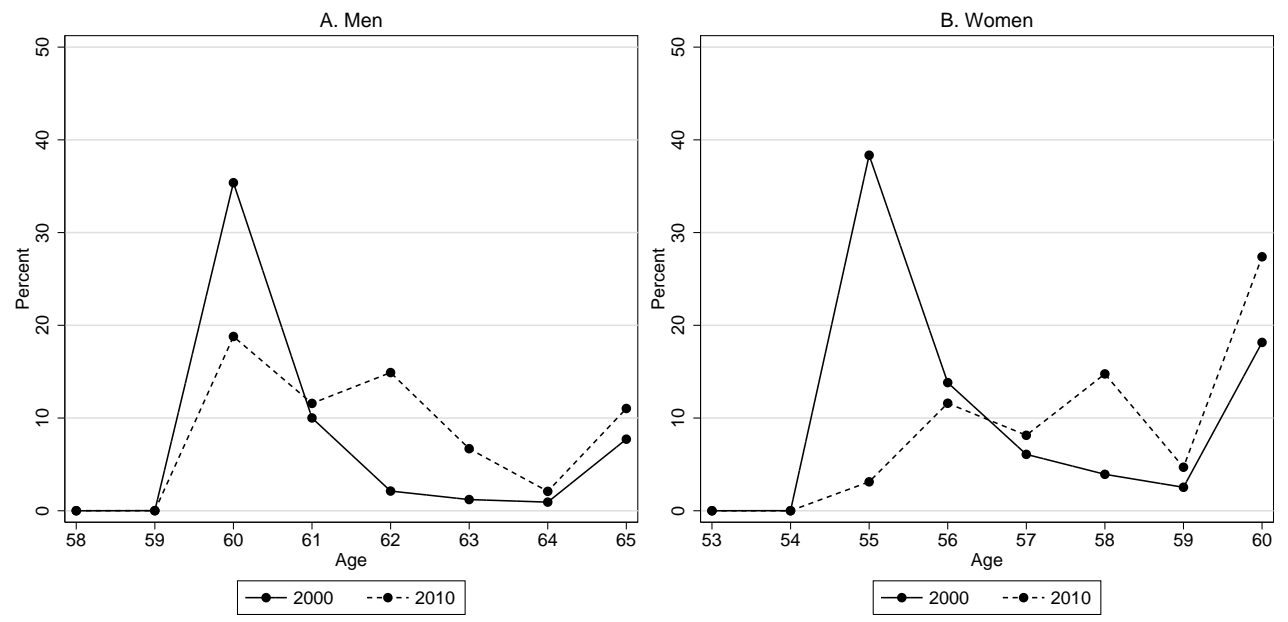

Figure 2: Age distribution of retirement entry of men (panel A) and women (panel B) in 2000 and 2010.

Source: Own calculations, based on Austrian Social Security Data. 

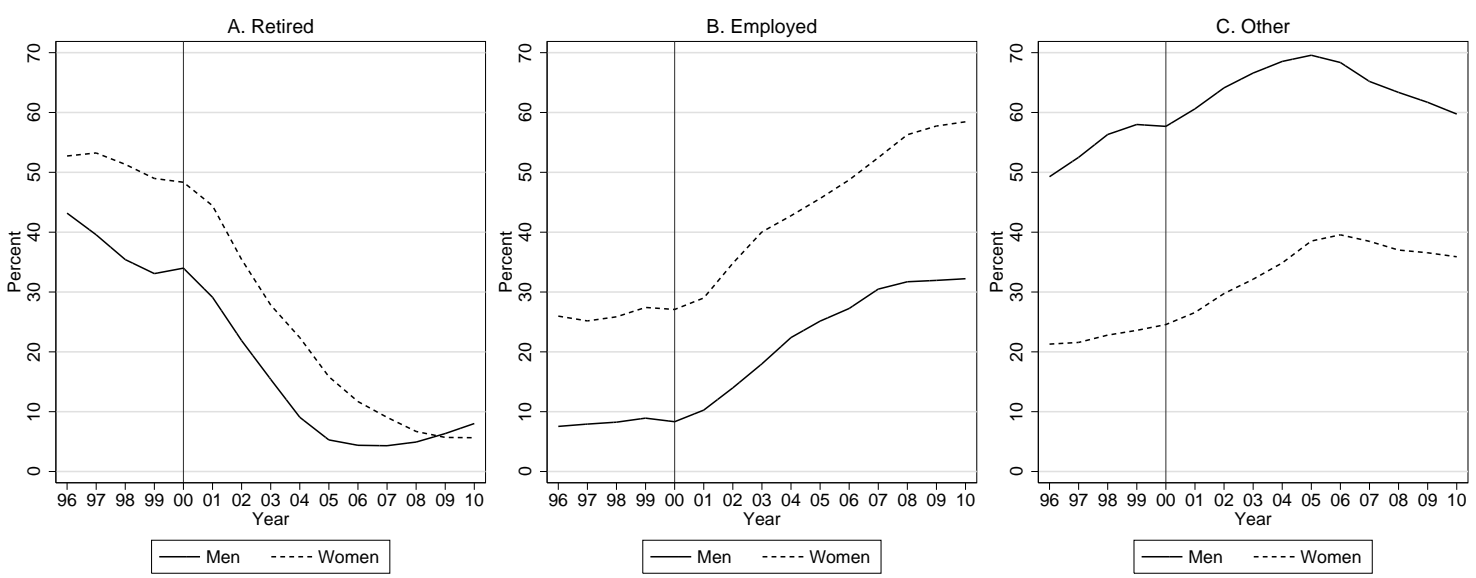

Figure 3: Trends in retirement, employment, and other states over time among men aged 60-62 and women aged 55-58.25.

Source: Own calculations, based on Austrian Social Security Data. 

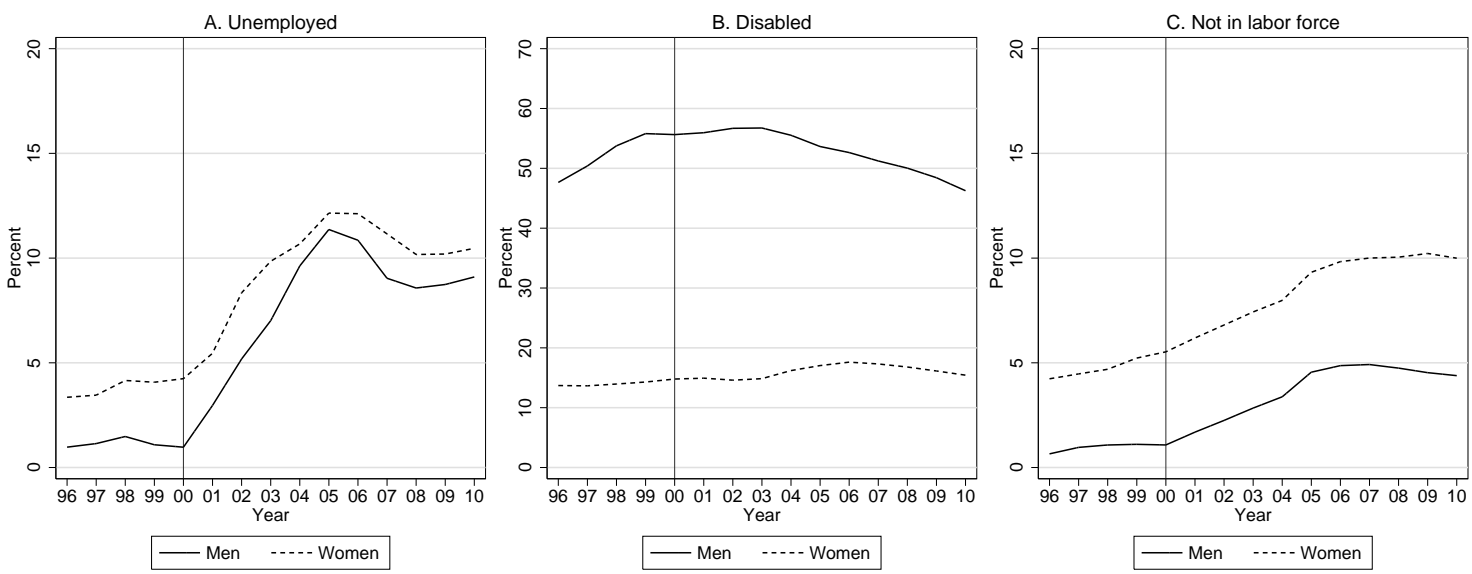

Figure 4: Trends in unemployment, disability, and not in labor force over time among men aged 60-62 and women aged 55-58.25.

Source: Own calculations, based on Austrian Social Security Data. 

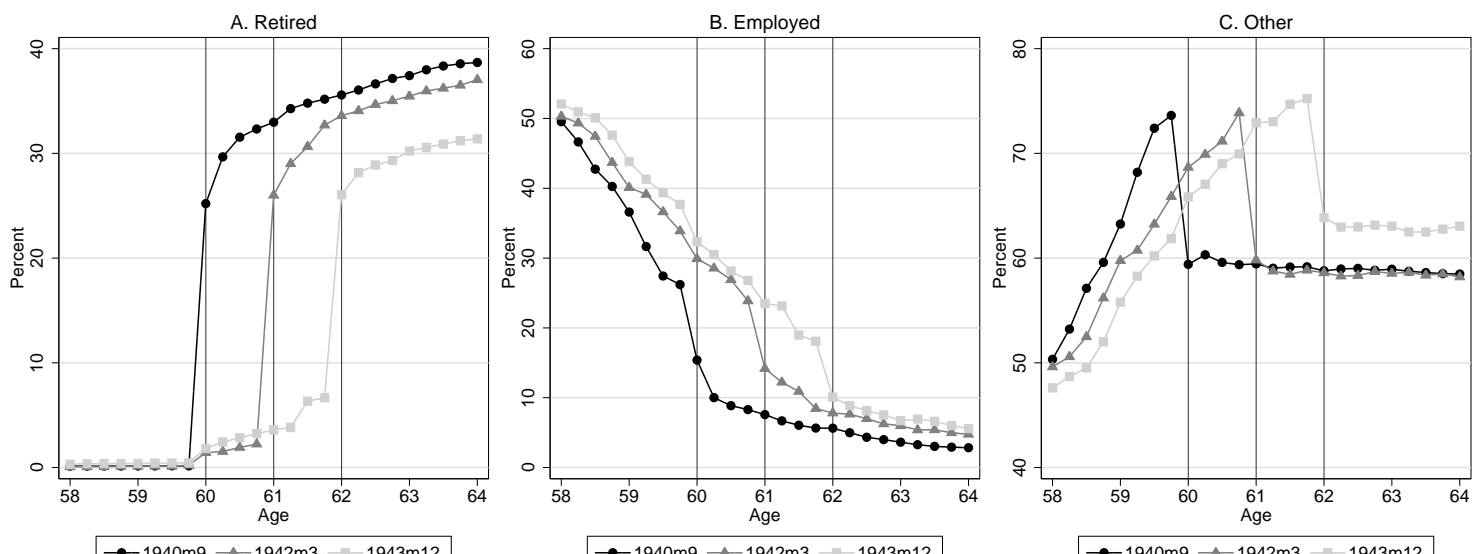

Figure 5: Trends in retirement, employment, and other states over age for men born in different months.

Source: Own calculations, based on Austrian Social Security Data. 

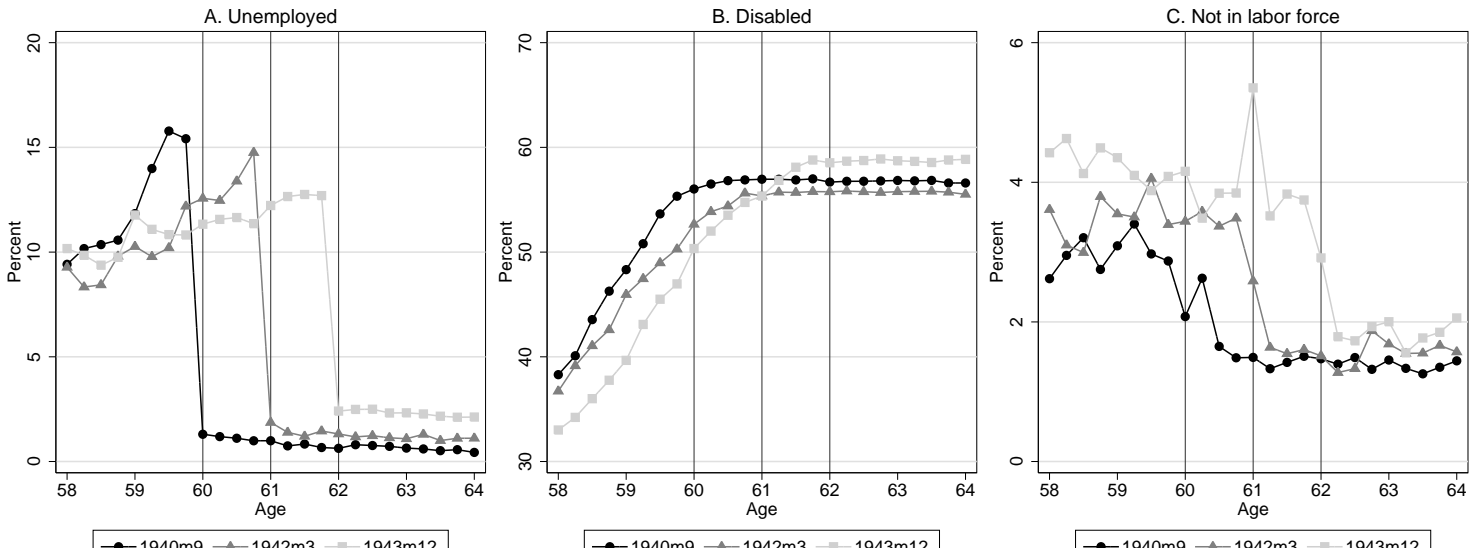

Figure 6: Trends in unemployment, disability, and not in labor force over age for men born in different months.

Source: Own calculations, based on Austrian Social Security Data. 

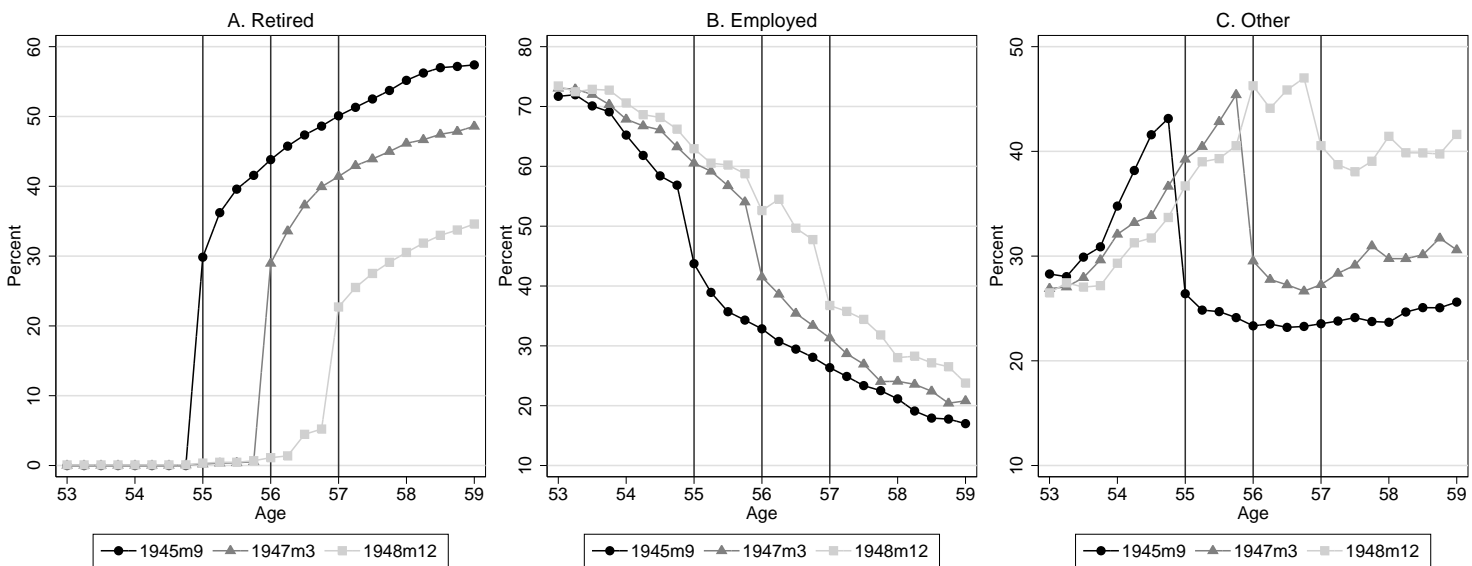

Figure 7: Trends in retirement, employment, and other states over age for women born in different months.

Source: Own calculations, based on Austrian Social Security Data. 

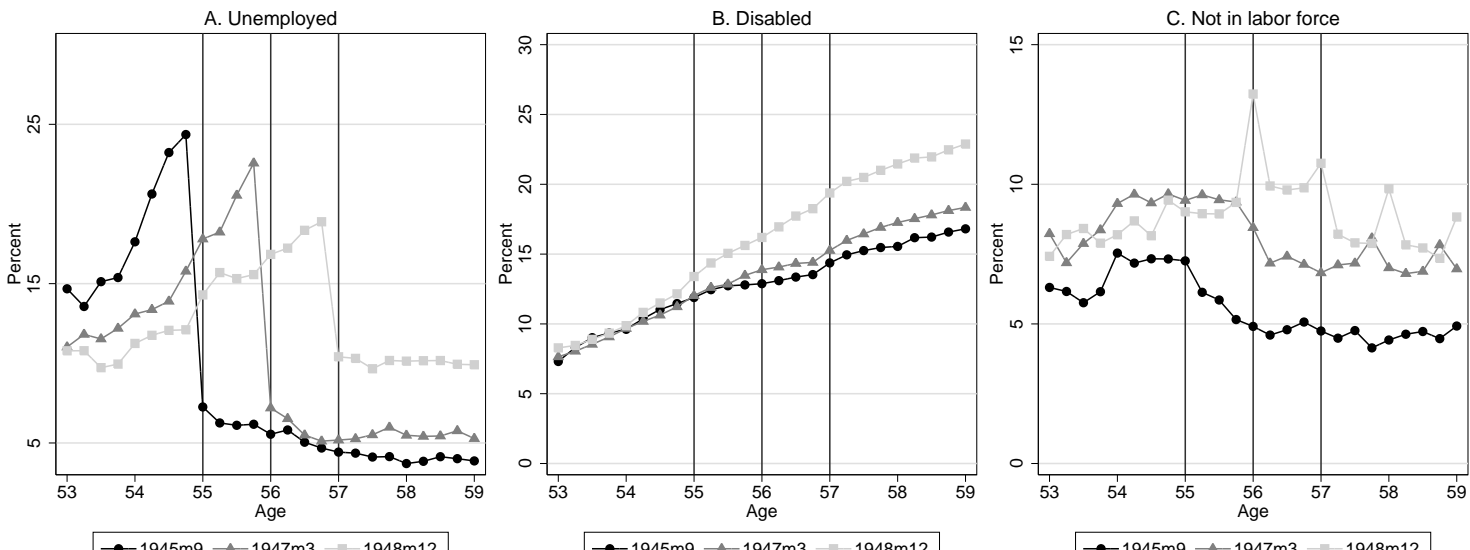

Figure 8: Trends in unemployment, disability, and not in labor force over age for women born in different months.

Source: Own calculations, based on Austrian Social Security Data. 
Table 1: Sample statistics for men aged $60-62.25$ and women aged $55-58.5$ by year

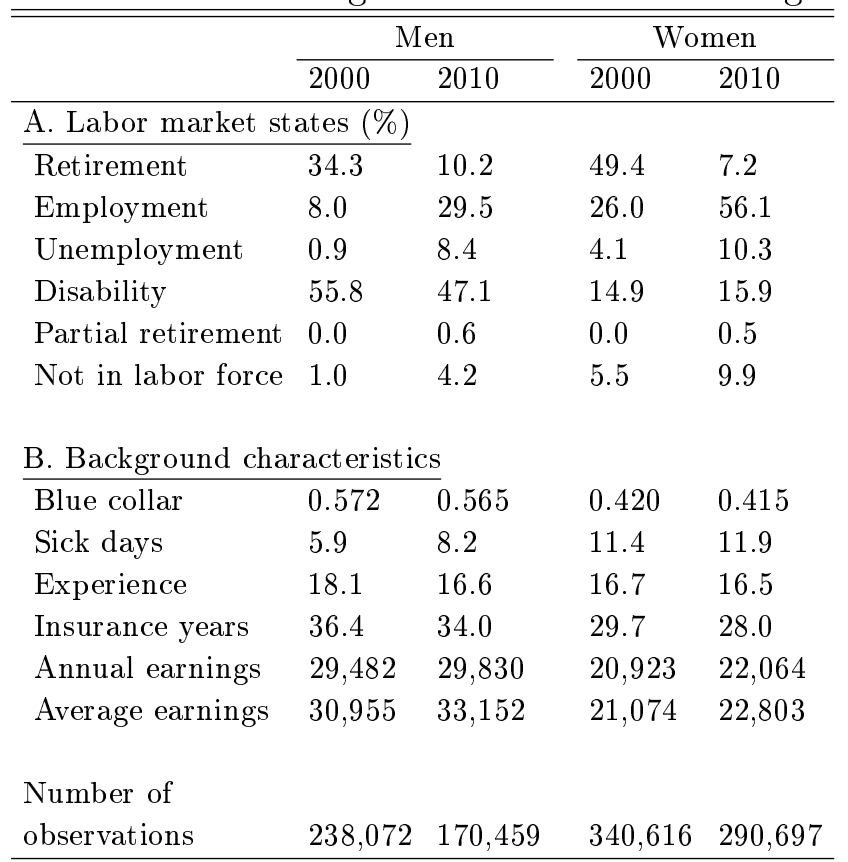

Notes: "Experience" denotes experience in the last 25 years, "sick days" is the sum of days spent in sick leave in the last 2 years, and "average earnings" is the average annual earnings over the best 15 years. Annual earnings and average earnings are adjusted for inflation. 
Table 2: Effects on retirement, employment, and other states

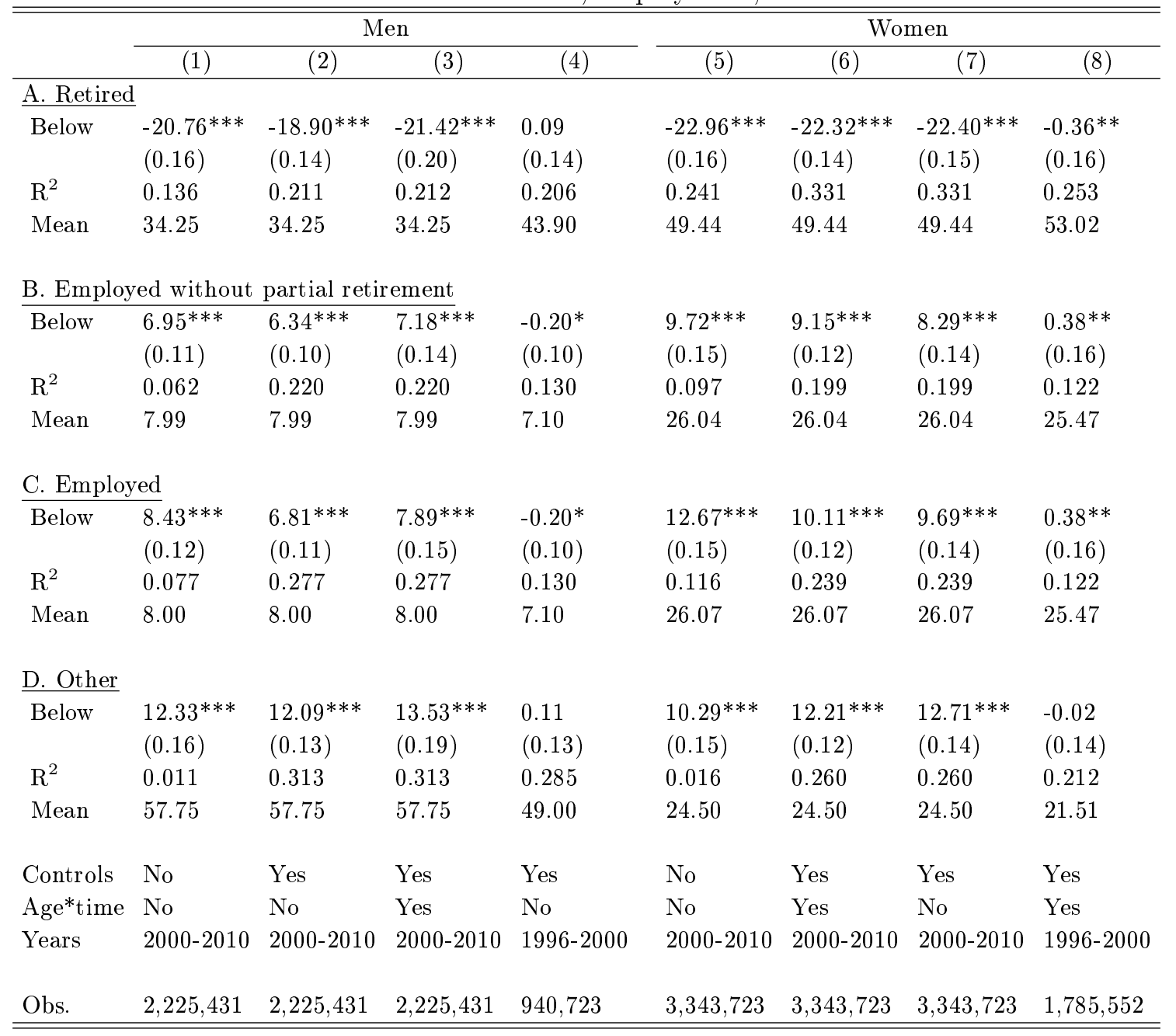

Notes: This Table displays coefficients from a linear probability model. Standard errors, in parentheses, are clustered at the individual level. Coefficient estimates and standard errors are multiplied by 100 and should be interpreted as percentage points. Controls are experience and its square, blue-collar status, number of insurance years, annual earnings, average earnings over the best 15 years, number of sick leave days in the last 2 years, industry, region and a fourth-order polynomial in month of birth. Columns (3) and (6) also include age-specific time trends. Annual earnings and average earnings are adjusted for inflation. Reported means are for men aged $60-62.25$ and women aged 55-58.5 in 2000. Significance levels: $* * *=1 \%, * *=5 \%$, $*=10 \%$. 
Table 3: Effects on unemployment, disability, and not in the labor force

\begin{tabular}{|c|c|c|c|c|c|c|c|c|}
\hline & \multicolumn{4}{|c|}{ Men } & \multicolumn{4}{|c|}{ Women } \\
\hline & $(1)$ & $(2)$ & $(3)$ & $(4)$ & $(5)$ & $(6)$ & $(7)$ & $(8)$ \\
\hline \multicolumn{9}{|c|}{ A. Unemployed } \\
\hline Below & $\begin{array}{l}10.50 * * * \\
(0.10)\end{array}$ & $\begin{array}{l}10.07^{* * *} \\
(0.10)\end{array}$ & $\begin{array}{l}11.75^{* * *} \\
(0.13)\end{array}$ & $\begin{array}{l}0.09^{*} \\
(0.05)\end{array}$ & $\begin{array}{l}8.46^{* * *} \\
(0.10)\end{array}$ & $\begin{array}{l}10.18^{* * *} \\
(0.10)\end{array}$ & $\begin{array}{l}10.37^{* * *} \\
(0.11)\end{array}$ & $\begin{array}{l}0.03 \\
(0.09)\end{array}$ \\
\hline $\mathrm{R}^{2}$ & 0.035 & 0.098 & 0.099 & 0.040 & 0.019 & 0.105 & 0.105 & 0.040 \\
\hline Mean & 0.94 & 0.94 & 0.94 & 0.92 & 4.09 & 4.09 & 4.09 & 3.28 \\
\hline \multicolumn{9}{|c|}{ B. Disabled } \\
\hline Below & $\begin{array}{l}0.46^{* * *} \\
(0.13)\end{array}$ & $\begin{array}{l}0.93^{* * *} \\
(0.10)\end{array}$ & $\begin{array}{l}0.58^{* * *} \\
(0.15)\end{array}$ & $\begin{array}{l}-0.06 \\
(0.12)\end{array}$ & $\begin{array}{l}-0.10 \\
(0.10)\end{array}$ & $\begin{array}{l}0.31^{* * *} \\
(0.07)\end{array}$ & $\begin{array}{l}0.56^{* * *} \\
(0.09)\end{array}$ & $\begin{array}{l}-0.04 \\
(0.11)\end{array}$ \\
\hline $\mathrm{R}^{2}$ & 0.006 & 0.275 & 0.275 & 0.286 & 0.004 & 0.092 & 0.092 & 0.106 \\
\hline Mean & 55.76 & 55.76 & 55.76 & 47.45 & 14.93 & 14.93 & 14.93 & 13.99 \\
\hline \multicolumn{9}{|c|}{ C. Not in labor force } \\
\hline Below & $\begin{array}{l}1.37^{* * *} \\
(0.05)\end{array}$ & $\begin{array}{l}1.09 * * * \\
(0.05)\end{array}$ & $\begin{array}{l}1.20 * * * \\
(0.07)\end{array}$ & $\begin{array}{l}0.08^{*} \\
(0.04)\end{array}$ & $\begin{array}{l}1.93^{* * *} \\
(0.08)\end{array}$ & $\begin{array}{l}1.71^{* * *} \\
(0.06)\end{array}$ & $\begin{array}{l}1.77^{* * *} \\
(0.07)\end{array}$ & $\begin{array}{l}-0.00 \\
(0.08)\end{array}$ \\
\hline $\mathrm{R}^{2}$ & 0.008 & 0.027 & 0.027 & 0.034 & 0.006 & 0.161 & 0.161 & 0.176 \\
\hline Mean & 1.04 & 1.04 & 1.04 & 0.63 & 5.48 & 5.48 & 5.48 & 4.23 \\
\hline Controls & No & Yes & Yes & Yes & No & Yes & Yes & Yes \\
\hline Age*time & No & No & Yes & No & No & Yes & No & Yes \\
\hline Years & $2000-2010$ & $2000-2010$ & $2000-2010$ & $1996-2000$ & $2000-2010$ & $2000-2010$ & $2000-2010$ & $1996-2000$ \\
\hline Obs. & $2,225,431$ & $2,225,431$ & $2,225,431$ & 940,723 & $3,343,723$ & $3,343,723$ & $3,343,723$ & $1,785,552$ \\
\hline
\end{tabular}

Notes: This Table displays coefficients from a linear probability model. Standard errors, in parentheses, are clustered at the individual level. Coefficient estimates and standard errors are multiplied by 100 and should be interpreted as percentage points. Controls are experience and its square, blue-collar status, number of insurance years, annual earnings, average earnings over the best 15 years, number of sick leave days in the last 2 years, industry, region and a fourth-order polynomial in month of birth. Columns (3) and (6) also include age-specific time trends. Annual earnings and average earnings are adjusted for inflation. Reported means are for men aged $60-62.25$ and women aged 55-58.5 in 2000 . Significance levels: ${ }^{* * *}=1 \%,{ }^{*}=5 \%$, $*=10 \%$. 
Table 4: Effect on transitions from employment and unemployment by gender Status at $t$ : Retired Employed Unemployed Disabled Not in

labor force

$\begin{array}{lllll}(1) & (2) & (3) & (4) & (5)\end{array}$

Notes: This Table displays coefficients from a linear probability model. Standard errors, in parentheses, are clustered at the individual level. Coefficient estimates and standard errors are multiplied by 100 and should be interpreted as percentage points. All estimates include controls for experience and its square, blue-collar status, number of insurance years, annual earnings, average earnings over the best 15 years, number of sick leave days in the last 2 years, industry, region and a fourth-order polynomial in month of birth. Annual earnings and average earnings are adjusted for inflation. The time period is 2000-2010. Reported means are for men aged $60-62.25$ and women aged $55-58.5$ in 2000 . Significance levels: $* * *=1 \%,{ }^{* *}=5 \%, *=$ $10 \%$. 
Table 5: Estimates for different ages

\begin{tabular}{|c|c|c|c|c|c|c|c|}
\hline \multicolumn{4}{|c|}{ Men } & \multicolumn{4}{|c|}{ Women } \\
\hline & $\begin{array}{l}\text { Retired } \\
\text { (1) }\end{array}$ & $\begin{array}{c}\text { Employed } \\
(2)\end{array}$ & $\begin{array}{c}\text { Unemployed } \\
(3)\end{array}$ & & $\begin{array}{l}\text { Retired } \\
\text { (4) }\end{array}$ & $\begin{array}{c}\text { Employed } \\
(5)\end{array}$ & $\begin{array}{c}\text { Unemployed } \\
(6)\end{array}$ \\
\hline Ages & & & & Ages & & & \\
\hline Below*60.5 & $\begin{array}{l}-23.31^{* * *} \\
(0.32)\end{array}$ & $\begin{array}{l}9.31^{* * *} \\
(0.23)\end{array}$ & $\begin{array}{l}12.84^{* * *} \\
(0.17)\end{array}$ & Below*55.5 & $\begin{array}{l}-25.52^{* * *} \\
(0.34)\end{array}$ & $\begin{array}{l}9.54^{* * *} \\
(0.34)\end{array}$ & $\begin{array}{l}12.95^{* * *} \\
(0.21)\end{array}$ \\
\hline Below*61 & $\begin{array}{l}-22.30^{* * *} \\
(0.21)\end{array}$ & $\begin{array}{l}8.61^{* * *} \\
(0.16)\end{array}$ & $\begin{array}{l}11.56^{* * *} \\
(0.13)\end{array}$ & Below*56 & $\begin{array}{l}-26.78^{* * *} \\
(0.25)\end{array}$ & $\begin{array}{l}11.26^{* * *} \\
(0.24)\end{array}$ & $\begin{array}{l}12.39^{* * *} \\
(0.17)\end{array}$ \\
\hline Below*61.5 & $\begin{array}{l}-20.45^{* * *} \\
(0.14)\end{array}$ & $\begin{array}{l}8.02^{* * *} \\
(0.12)\end{array}$ & $\begin{array}{l}9.93 * * * \\
(0.11)\end{array}$ & Below*56.5 & $\begin{array}{l}-26.43^{* * *} \\
(0.18)\end{array}$ & $\begin{array}{l}12.51^{* * *} \\
(0.17)\end{array}$ & $\begin{array}{l}11.27^{* * *} \\
(0.14)\end{array}$ \\
\hline Below*62 & $\begin{array}{l}-15.26^{* * *} \\
(0.12)\end{array}$ & $\begin{array}{l}4.53^{* * *} \\
(0.10)\end{array}$ & $\begin{array}{l}9.07 * * * \\
(0.10)\end{array}$ & Below*57 & $\begin{array}{l}-22.13^{* * *} \\
(0.14)\end{array}$ & $\begin{array}{l}10.15^{* * *} \\
(0.14)\end{array}$ & $\begin{array}{l}10.40^{* * *} \\
(0.12)\end{array}$ \\
\hline & & & & Below*57.5 & $\begin{array}{l}-19.50^{* * *} \\
(0.13)\end{array}$ & $\begin{array}{l}9.04^{* * *} \\
(0.13)\end{array}$ & $\begin{array}{l}8.84^{* * *} \\
(0.11)\end{array}$ \\
\hline & & & & Below*58 & $\begin{array}{l}-17.67^{* * *} \\
(0.17)\end{array}$ & $\begin{array}{l}7.77^{* * *} \\
(0.19)\end{array}$ & $\begin{array}{l}8.29 * * * \\
(0.15)\end{array}$ \\
\hline $\mathrm{R}^{2}$ & 0.212 & 0.277 & 0.098 & & 0.331 & 0.239 & 0.105 \\
\hline Obs. & $2,225,431$ & $2,225,431$ & $2,225,431$ & & $3,343,723$ & $3,343,723$ & $3,343,723$ \\
\hline
\end{tabular}

Notes: This Table displays coefficients from a linear probability model. Standard errors, in parentheses, are clustered at the individual level. Coefficient estimates and standard errors are multiplied by 100 and should be interpreted as percentage points. All estimates include controls for experience and its square, blue-collar status, number of insurance years, annual earnings, average earnings over the best 15 years, number of sick leave days in the last 2 years, industry, region and a fourth-order polynomial in month of birth. Annual earnings and average earnings are adjusted for inflation. The time period is 2000-2010. Reported means are for men aged $60-62.25$ and women aged $55-58.5$ in 2000 . Significance levels: ${ }^{* * *}=1 \%,{ }^{* *}=5 \%,{ }^{*}=$ $10 \%$. 
Table 6: Estimates by health status and quartiles of life-time earnings for men

\begin{tabular}{|c|c|c|c|c|c|c|c|c|}
\hline & \multicolumn{4}{|c|}{ Healthy } & \multicolumn{4}{|c|}{ Unhealthy } \\
\hline & $\begin{array}{c}\text { 1st } \\
\text { quartile } \\
(1)\end{array}$ & $\begin{array}{c}2 \text { nd } \\
\text { quartile } \\
(2)\end{array}$ & $\begin{array}{c}\text { 3rd } \\
\text { quartile } \\
(3)\end{array}$ & $\begin{array}{c}4 \text { th } \\
\text { quartile } \\
(4)\end{array}$ & $\begin{array}{c}\text { 1st } \\
\text { quartile } \\
(5)\end{array}$ & $\begin{array}{c}2 \mathrm{nd} \\
\text { quartile } \\
(6)\end{array}$ & $\begin{array}{c}\text { 3rd } \\
\text { quartile } \\
(7)\end{array}$ & $\begin{array}{c}4 \text { th } \\
\text { quartile } \\
(8)\end{array}$ \\
\hline \multicolumn{9}{|c|}{ A. Retired } \\
\hline Below & $\begin{array}{l}-17.39^{* * *} \\
(0.38)\end{array}$ & $\begin{array}{l}-20.54^{* * *} \\
(0.41)\end{array}$ & $\begin{array}{l}-27.49^{* * *} \\
(0.44)\end{array}$ & $\begin{array}{l}-31.93^{* * *} \\
(0.44)\end{array}$ & $\begin{array}{l}-12.76^{* * *} \\
(0.32)\end{array}$ & $\begin{array}{l}-11.73^{* * *} \\
(0.32)\end{array}$ & $\begin{array}{l}-12.23^{* * *} \\
(0.33)\end{array}$ & $\begin{array}{l}-16.43^{* * *} \\
(0.38)\end{array}$ \\
\hline $\mathrm{R}^{2}$ & 0.171 & 0.199 & 0.233 & 0.359 & 0.140 & 0.164 & 0.180 & 0.205 \\
\hline Mean & 31.45 & 41.29 & 47.24 & 61.56 & 17.05 & 20.15 & 24.56 & 30.13 \\
\hline \multicolumn{9}{|c|}{$\underline{\text { B. Employed }}$} \\
\hline Below & $\begin{array}{l}7.35^{* * *} \\
(0.33)\end{array}$ & $\begin{array}{l}8.23^{* * *} \\
(0.32)\end{array}$ & $\begin{array}{l}7.38^{* * *} \\
(0.32)\end{array}$ & $\begin{array}{l}18.46^{* * *} \\
(0.40)\end{array}$ & $\begin{array}{l}2.36^{* * *} \\
(0.20)\end{array}$ & $\begin{array}{l}3.02^{* * *} \\
(0.21)\end{array}$ & $\begin{array}{l}3.21^{* * *} \\
(0.21)\end{array}$ & $\begin{array}{l}3.90 * * * \\
(0.24)\end{array}$ \\
\hline $\mathrm{R}^{2}$ & 0.143 & 0.228 & 0.240 & 0.439 & 0.097 & 0.157 & 0.209 & 0.283 \\
\hline Mean & 12.74 & 6.81 & 8.06 & 25.64 & 3.46 & 2.24 & 1.70 & 3.06 \\
\hline \multicolumn{9}{|c|}{ C. Unemployed } \\
\hline Below & $\begin{array}{l}8.40 * * * \\
(0.27)\end{array}$ & $\begin{array}{l}10.81^{* * *} \\
(0.28)\end{array}$ & $\begin{array}{l}15.93^{* * *} \\
(0.32)\end{array}$ & $\begin{array}{l}10.44^{* * *} \\
(0.26)\end{array}$ & $\begin{array}{l}9.10^{* * *} \\
(0.28)\end{array}$ & $\begin{array}{l}7.79 * * * \\
(0.25)\end{array}$ & $\begin{array}{l}7.76^{* * *} \\
(0.24)\end{array}$ & $\begin{array}{l}10.36^{* * *} \\
(0.27)\end{array}$ \\
\hline $\mathrm{R}^{2}$ & 0.089 & 0.109 & 0.146 & 0.073 & 0.116 & 0.100 & 0.093 & 0.120 \\
\hline Mean & 2.69 & 0.59 & 0.32 & 0.45 & 2.22 & 0.56 & 0.46 & 0.24 \\
\hline Obs. & 278,973 & 279,598 & 279,099 & 280,113 & 276,428 & 277,049 & 276,801 & 277,370 \\
\hline
\end{tabular}

Notes: This Table displays coefficients from a linear probability model. Standard errors, in parentheses, are clustered at the individual level. Coefficient estimates and standard errors are multiplied by 100 and should be interpreted as percentage points. All estimates include controls for experience and its square, blue-collar status, number of insurance years, annual earnings, average earnings over the best 15 years, number of sick leave days in the last 2 years, industry, region and a fourth-order polynomial in month of birth. Annual earnings and average earnings are adjusted for inflation. The time period is 2000-2010. Reported means are for men aged $60-62.25$ and women aged 55-58.5 in 2000 . Significance levels: $* * *=1 \%,{ }^{* *}=5 \%,{ }^{*}=$ $10 \%$. 
Table 7: Estimates by health status and quartiles of life-time earnings for women

\begin{tabular}{|c|c|c|c|c|c|c|c|c|}
\hline & \multicolumn{4}{|c|}{ Healthy } & \multicolumn{4}{|c|}{ Unhealthy } \\
\hline & $\begin{array}{c}\text { 1st } \\
\text { quartile } \\
\text { (1) }\end{array}$ & $\begin{array}{c}2 \text { nd } \\
\text { quartile } \\
(2)\end{array}$ & $\begin{array}{c}\text { 3rd } \\
\text { quartile } \\
(3)\end{array}$ & $\begin{array}{c}4 \mathrm{th} \\
\text { quartile } \\
(4)\end{array}$ & $\begin{array}{c}\text { 1st } \\
\text { quartile } \\
(5)\end{array}$ & $\begin{array}{c}2 \text { nd } \\
\text { quartile } \\
(6)\end{array}$ & $\begin{array}{c}\text { 3rd } \\
\text { quartile } \\
(7)\end{array}$ & $\begin{array}{c}4 \mathrm{th} \\
\text { quartile } \\
(8)\end{array}$ \\
\hline \multicolumn{9}{|c|}{ A. Retired } \\
\hline Below & $\begin{array}{l}-9.99 * * * \\
(0.29)\end{array}$ & $\begin{array}{l}-17.05^{* * *} \\
(0.36)\end{array}$ & $\begin{array}{l}-22.68^{* * *} \\
(0.39)\end{array}$ & $\begin{array}{l}-23.29 * * * \\
(0.40)\end{array}$ & $\begin{array}{l}-17.52^{* * *} \\
(0.35)\end{array}$ & $\begin{array}{l}-24.76^{* * *} \\
(0.38)\end{array}$ & $\begin{array}{l}-29.50^{* * *} \\
(0.41)\end{array}$ & $\begin{array}{l}-33.89^{* * *} \\
(0.42)\end{array}$ \\
\hline $\mathrm{R}^{2}$ & 0.248 & 0.309 & 0.339 & 0.353 & 0.300 & 0.350 & 0.367 & 0.377 \\
\hline Mean & 28.19 & 43.48 & 54.78 & 61.26 & 39.25 & 50.53 & 56.14 & 61.88 \\
\hline \multicolumn{9}{|c|}{ B. Employed } \\
\hline Below & $\begin{array}{l}5.89^{* * *} \\
(0.33)\end{array}$ & $\begin{array}{l}9.92^{* * *} \\
(0.35)\end{array}$ & $\begin{array}{l}14.84^{* * *} \\
(0.38)\end{array}$ & $\begin{array}{l}15.76^{* * *} \\
(0.38)\end{array}$ & $\begin{array}{l}5.62^{* * *} \\
(0.28)\end{array}$ & $\begin{array}{l}7.21^{* * *} \\
(0.30)\end{array}$ & $\begin{array}{l}9.92^{* * *} \\
(0.33)\end{array}$ & $\begin{array}{l}11.18^{* * *} \\
(0.34)\end{array}$ \\
\hline $\mathrm{R}^{2}$ & 0.208 & 0.246 & 0.272 & 0.292 & 0.110 & 0.128 & 0.166 & 0.230 \\
\hline Mean & 41.49 & 37.77 & 33.96 & 32.11 & 17.26 & 14.50 & 15.93 & 15.08 \\
\hline \multicolumn{9}{|c|}{ C. Unemployed } \\
\hline Below & $\begin{array}{l}2.71^{* * *} \\
(0.22)\end{array}$ & $\begin{array}{l}5.92^{* * *} \\
(0.26)\end{array}$ & $\begin{array}{l}6.70^{* * *} \\
(0.24)\end{array}$ & $\begin{array}{l}6.31^{* * *} \\
(0.21)\end{array}$ & $\begin{array}{l}9.43^{* * *} \\
(0.30)\end{array}$ & $\begin{array}{l}14.46^{* * *} \\
(0.33)\end{array}$ & $\begin{array}{l}16.80^{* * *} \\
(0.33)\end{array}$ & $\begin{array}{l}19.44^{* * *} \\
(0.33)\end{array}$ \\
\hline $\mathrm{R}^{2}$ & 0.053 & 0.061 & 0.065 & 0.059 & 0.108 & 0.127 & 0.132 & 0.148 \\
\hline Mean & 6.01 & 5.09 & 3.02 & 1.21 & 6.72 & 5.22 & 3.56 & 1.92 \\
\hline Obs. & 419,450 & 420,404 & 419,935 & 420,915 & 415,022 & 415,982 & 415,540 & 416,475 \\
\hline
\end{tabular}

Notes: This Table displays coefficients from a linear probability model. Standard errors, in parentheses, are clustered at the individual level. Coefficient estimates and standard errors are multiplied by 100 and should be interpreted as percentage points. All estimates include controls for experience and its square, blue-collar status, number of insurance years, annual earnings, average earnings over the best 15 years, number of sick leave days in the last 2 years, industry, region and a fourth-order polynomial in month of birth. Annual earnings and average earnings are adjusted for inflation. The time period is 2000-2010. Reported means are for men aged $60-62.25$ and women aged $55-58.5$ in 2000 . Significance levels: ${ }^{* * *}=1 \%,{ }^{* *}=5 \%,{ }^{*}=$ $10 \%$.

Table 8: Effect on annual government net expenditures (in million euros)

\begin{tabular}{|c|c|c|c|c|c|}
\hline & $\begin{array}{c}\text { Potential } \Delta \text { in } \\
\text { net expenditures } \\
\text { (A) }\end{array}$ & $\begin{array}{l}\text { Effective } \Delta \text { in } \\
\text { retirement benefits } \\
\text { (B) }\end{array}$ & $\begin{array}{l}\text { Effective } \Delta \text { in } \\
\text { tax revenues } \\
\text { (C) }\end{array}$ & $\begin{array}{l}\text { Effective } \Delta \text { in } \\
\text { UI \& DI benefits } \\
\text { (D) }\end{array}$ & $\begin{array}{c}\text { Effective } \Delta \text { in } \\
\text { net expenditures } \\
\quad(B-C+D)\end{array}$ \\
\hline Men & -124.1 & -72.7 & 19.4 & 27.6 & -64.5 \\
\hline Women & -139.9 & -84.8 & 27.8 & 29.2 & -83.4 \\
\hline $\begin{array}{l}\text { Total } \\
(\Delta \text { in } \%)\end{array}$ & $\begin{array}{c}-264.0 \\
(-54.8 \%)\end{array}$ & $\begin{array}{c}-157.5 \\
(-49.8 \%)\end{array}$ & $\begin{array}{c}47.2 \\
(55.5 \%)\end{array}$ & $\begin{array}{c}56.8 \\
(22.7 \%)\end{array}$ & $\begin{array}{c}-147.9 \\
(-30.7 \%)\end{array}$ \\
\hline
\end{tabular}

Notes: Notes: The first column represents the potential change in annual net expenditures if the reduction in early retirement was entirely compensated by an increase in employment. The last column shows the effective change in annual net expenditures, which is equal to the change in retirement benefits paid (column B), the change in tax revenues received (column C), and the change in UI \& DI benefits paid (column D). All values are adjusted for inflation. $\Delta$ in $\%$ measures the change relative to the year 2000 . For more details on the calculation see main text. 
Table 9: Effect on annual government net expenditures by subgroups (in million euros) $\begin{array}{lllll}\text { Potential } \Delta \text { in } & \text { Effective } \Delta \text { in } & \text { Effective } \Delta \text { in } & \text { Effective } \Delta \text { in } & \text { Effective } \Delta \text { in }\end{array}$ net expenditures retirement benefits tax revenues UI \& DI benefits net expenditures (A) (B) (C) (D) $(\mathrm{B}-\mathrm{C}+\mathrm{D})$

\begin{tabular}{|c|c|c|c|c|c|}
\hline \multicolumn{6}{|l|}{ A. Men } \\
\hline \multicolumn{6}{|l|}{ Healthy } \\
\hline$\overline{\text { 1st quartile }}$ & -7.6 & -5.1 & 1.0 & 1.9 & -4.2 \\
\hline 2nd quartile & -15.5 & -9.5 & 2.3 & 3.6 & -8.2 \\
\hline 3rd quartile & -27.8 & -15.8 & 3.2 & 6.6 & -12.4 \\
\hline 4th quartile & -39.3 & -20.3 & 10.0 & 5.5 & -24.8 \\
\hline \multicolumn{6}{|l|}{ Unhealthy } \\
\hline$\overline{\text { 1st quartile }}$ & -4.5 & -3.4 & 0.2 & 1.7 & -1.9 \\
\hline 2nd quartile & -6.2 & -4.3 & 0.5 & 2.0 & -2.8 \\
\hline 3rd quartile & -8.3 & -5.4 & 0.8 & 2.3 & -3.9 \\
\hline 4th quartile & -14.9 & -8.9 & 1.4 & 4.0 & -6.3 \\
\hline \multicolumn{6}{|l|}{ B. Women } \\
\hline \multicolumn{6}{|l|}{ Healthy } \\
\hline$\overline{\text { 1st quartile }}$ & -2.7 & -2.0 & 0.4 & 0.5 & -1.9 \\
\hline 2nd quartile & -9.8 & -6.3 & 2.0 & 1.8 & -6.5 \\
\hline 3rd quartile & -20.6 & -11.9 & 5.7 & 2.9 & -14.7 \\
\hline 4th quartile & -34.9 & -17.7 & 11.6 & 3.9 & -25.4 \\
\hline \multicolumn{6}{|l|}{ Unhealthy } \\
\hline$\overline{\text { 1st quartile }}$ & -5.0 & -3.9 & 0.4 & 1.8 & -2.5 \\
\hline 2nd quartile & -11.7 & -8.5 & 0.9 & 3.8 & -5.6 \\
\hline 3rd quartile & -19.6 & -13.3 & 2.1 & 5.4 & -10.0 \\
\hline 4th quartile & -35.6 & -21.2 & 4.7 & 9.1 & -16.8 \\
\hline Total & -264 & -157.5 & 47.2 & 56.8 & -147.9 \\
\hline
\end{tabular}

Notes: The first column represents the potential change in annual net expenditures if the reduction in early retirement was entirely compensated by an increase in employment. The last column shows the effective change in annual net expenditures, which is equal to the change in retirement benefits paid (column B), the change in tax revenues received (column C), and the change in UI \& DI benefits paid (column D). All values are adjusted for inflation. For more details on the calculation see main text. 